Please do not remove this page

RMIT

UNIVERSITY

\title{
Design, synthesis, and subtype selectivity of 3,6-disubstituted b-carbolines at Bz/GABA(A)ergic receptors. SAR and studies directed toward agents for treatment of alcohol abuse
}

Yin, Wenyuan; Majumder, Samarpan; Clayton, Terry; Petrou, Steven; VanLinn, Michael; Namjoshi, Ojas; Ma, Chunrong

https://researchrepository.rmit.edu.au/esploro/outputs/9921858064801341/filesAndLinks?institution=61RMIT_INST\&index=null

Yin, W., Majumder, S., Clayton, T., Petrou, S., VanLinn, M., Namjoshi, O., Ma, C., Cromer, B., Roth, B., Platt, D., \& Cook, J. (2010). Design, synthesis, and subtype selectivity of 3,6-disubstituted b-carbolines at Bz/GABA(A)ergic receptors. SAR and studies directed toward agents for treatment of alcohol abuse. Bioorganic \& Medicinal Chemistry, 18(21), 7548-7564. https://doi.org/10.1016/j.bmc.2010.08.049 Document Version: Submitted Version

Published Version: https://doi.org/10.1016/j.bmc.2010.08.049

Repository homepage: https://researchrepository.rmit.edu.au (C) 2010 Elsevier Ltd

Downloaded On 2023/04/26 20:57:05 +1000 


\section{Design, Synthesis and Subtype Selectivity effects of 3,}

\section{6-Disubstituted $\quad \beta$-carbolines at $\mathrm{Bz} / \mathrm{GABA}(\mathrm{A})$ ergic}

\section{Receptors. SAR and Studies Directed Toward Agents}

\section{For Treatment of Alcohol Abuse.}

Citation:

Yin, W, Majumder, S, Clayton, T, Petrou, S, VanLinn, M, Namjoshi, O, Ma, C, Cromer, B, Roth, B, Platt, D and Cook, J 2010, 'Design, synthesis, and subtype selectivity of 3,6-disubstituted b-carbolines at Bz/GABA(A)ergic receptors. SAR and studies directed toward agents for treatment of alcohol abuse', Bioorganic \& Medicinal Chemistry, vol. 18, no. 21, pp. 7548-7564.

Wenyuan Yin ${ }^{l}$, Samarpan Majumder, ${ }^{2}$ Terry Clayton, ${ }^{I}$ Steven Petrou, ${ }^{3}$ Michael VanLinn, ${ }^{1}$ Chunrong

$$
\text { Ma, }{ }^{1} \text { Brett A. Cromer, }{ }^{3,4} \text { Bryan L. Roth, }{ }^{2} \text { and James M. Cook }{ }^{1 *}
$$

1. Department of Chemistry and Biochemistry, University of Wisconsin-Milwaukee, Milwaukee, WI, 53201-0413

2. University of North Carolina-Chapel Hill , 120 Mason Farm Road , 2113 Genetics Medicine Bldg, Chapel Hill, NC 27599-7365

3. Howard Florey Institute, University of Melbourne, Parkville, VIC 3010, Australia.

4. Department of Pharmacology, University of Melbourne, Parkville, VIC 3010, Australia.

*capncook@uwm.edu

\section{RECEIVED DATE}


Abstract:

A series of 3,6-disubstituted $\beta$-carbolines was synthesized and evaluated for their in vitro affinities at $\alpha_{x} \beta_{3} \gamma_{2} \mathrm{GABA}_{\mathrm{A}} /$ benzodiazepine receptor subtypes by radioligand binding assays in search of $\alpha_{1}$ subtype selective ligands to treat alcohol abuse. Analogues of $\beta$-carboline-3-carboxylate-t-butyl ester $(\beta C C t, \mathbf{1})$ were synthesized via a CDI-mediated process and the related 6 -substituted $\beta$-carboline-3carboxylates 6 including WYS8 (7) were synthesized via a Sonogashira or Stille coupling processes from 6-iodo $\beta C C t(5)$. The bivalent ligands of $\beta C C t$ (32 and 33) were also designed and prepared via a palladium-catalyzed homocoupling process to expand the SAR to larger ligands. Based on the pharmacophore/receptor model, a preliminary structure-activity relationship (SAR) study on 34 analogues illustrated that large substituents at position -6 of the $\beta$-carbolines were well tolerated. As expected, these groups are proposed to project into the extracellular domain ( $\mathrm{L}_{\mathrm{Di}}$ region) of $\mathrm{GABA}_{\mathrm{A}} / \mathrm{Bz}$ receptors (see 32 and 33). Moreover, substituents located at position -3 of the $\beta$-carboline nucleus exhibited a conserved stereo interaction in lipophilic pocket $\mathrm{L}_{1}$, while $\mathrm{N}(2)$ presumably underwent a hydrogen bonding interaction with $\mathrm{H}_{1}$. Three novel $\beta$-carboline ligands ( $\beta \mathrm{CCt}$, 3PBC and WYS8), which preferentially bound to $\alpha 1$ BzR subtypes permitted a comparison of the physiological efficacies with a range of classical BzR antagonists (flumazenil, ZK93426) from several different structural groups and indicated these betacarbolines were "near GABA neutral antagonists". Based on the SAR, the most potent (in vitro) $\alpha_{1}$ selective ligand was the 6-substituted acetylenyl $\beta C C t$ (WYS8, 7). Both $\beta c c t$ and 3PBC reduced alcohol administration in alcohol preferring $(\mathrm{P})$ and high alcohol drinking (HAD) rats but had little or no effect on sucrose self-administration. Moreover, these two betacarbolines were orally active, and in addition, were anxiolytic in $\mathbf{P}$ rats but were only weakly anxiolytic in rodent. ${ }^{1-3}$ These data prompted the synthesis of the betacarbolines presented here.

\section{Introduction:}


Alcoholism

Alcohol addiction and dependence remain a significant public health concern, impacting physical and mental well-being, family structure and occupational stability. ${ }^{4}$ While advances have been made in the development of novel therapies to treat alcoholism, ${ }^{5-8}$ alcohol-dependent individuals represent a heterogeneous group,${ }^{9-11}$ and it is unlikely that a single pharmacological treatment will be effective for all alcoholics. Hence, a better understanding of the neuromechanisms which regulate alcohol seeking behaviors and the design of clinically safe and effective drugs that reduce alcohol addiction and dependence remain a high priority. ${ }^{7,12}$ While the precise neuromechanisms regulating alcohol-seeking behaviors remain unknown, there is now compelling evidence that the $\mathrm{GABA}_{\mathrm{A}}$ receptors within the striatopallidal and extended amygdala system are involved in the "acute" reinforcing actions of alcohol. ${ }^{13-15}$ The striatopallidal and extended amygdala system include the sublenticular extended amygdala [substantia innominata/ventral pallidum (VP)], shell of the nucleus accumbens (NACC), and central nucleus of the amygdala. ${ }^{16-18}$ Among the potential GABA $\mathrm{A}_{\mathrm{A}}$ receptor isoforms within the VP regulating alcohol-seeking behaviors, GABA receptors containing the $\alpha 1$ receptor subtype (GABA $\alpha 1)$ appear preeminent. Thus, Criswell observed that acute alcohol administration selectively enhanced the effects of ionotophoretically applied GABA in the ventral pallidum (VP). ${ }^{19,20}$ However, no effects were seen in the septum, ventral tegmental area (VTA), and 
CAI hippocampus. Further, a positive correlation was observed between alcohol-induced $\mathrm{GABA}_{\mathrm{A}}$

enhancement and $\left[{ }^{3} \mathrm{H}\right]$ zolpidem binding (an $\alpha 1$ subtype selective agonist). These data suggest the $\alpha_{1}$

$\mathrm{Bz} / \mathrm{Gaba}(\mathrm{A})$ ergic receptor plays an important role in alcohol-motivated behaviors.

Research on the neuroanatomical basis of alcohol reward has shown that the NACC, VTA, VP, central amygdala (CeA), and hippocampus are involved in GABAergic regulation of ethanol (EtoH)

reinforcement. $^{2,21-24}$

Other investigators have identified a dense reciprocal projection from the VP to the NACC, ${ }^{25-27}$ and many of these have been found to be GABAergic neurons. ${ }^{28-30}$ The NACC is now well established as a substrate that regulates the reinforcing properties of abused drugs. ${ }^{13}$

Finally, immunohistochemical ${ }^{31,32}$ and in situ hybridization studies ${ }^{33-35}$ have demonstrated that the VP contains one of the highest concentrations of mRNA encoding the $\alpha_{1}$ subunit in the CNS. These findings, together with pharmacological studies suggesting the VP plays a role in reward-mediated behaviors of psychostimulants and opiates, ${ }^{28,36-39}$ suggest a possible role of the VP- $\alpha 1$ receptors in the euphoric properties of alcohol.

Animal Models

To model the human condition of alcohol abuse, rodents from the alcohol 'preferring' (P) line 
were studied. The P rat line has been shown to satisfy all criteria for an animal model of human alcohol abuse. $^{9,15,40,41}$ Findings of previous studies concluded that activation of VP- $\alpha 1$ receptors by the $\alpha 1$ preferring antagonist 3-PBC produced marked reductions on alcohol-maintained responding (June et al patent). The al-mediated suppression at the VP level by 3-PBC showed a high degree of neuroanatomical specificity. Specifically, the $\alpha_{1}$-mediated suppression was not observed with the more dorsal placements in the NACC or caudate putamen. The failure of 3-PBC to alter alcohol selfadministration in the NACC/striatum is in agreement with previous research which has consistently reported a lack of expression of the $\alpha_{1}$ transcript in the NACC and caudate $;^{31-34,42}$ and weak binding of $\left[{ }^{3} \mathrm{H}\right]$ zolpidem binding, the $\alpha_{1}$ selective agonist. Thus, Criswell and his colleagues ${ }^{19,20,35}$ have suggested zolpidem binding sites may be predictive of loci where ethanol activates GABAergic receptors in the CNS.

An understanding of the neuromechanisms that regulate alcohol drinking is key in the development of drugs to treat alcohol addiction and dependence in humans. ${ }^{2}$ In recent years, much evidence has accumulated in favor of the GABA system. ${ }^{22,23,43,44}$ However, despite the growing body of evidence in favor of the GABA system, much remains unknown about the role of specific $\mathrm{GABA}_{\mathrm{A}}$ receptor subtypes in regulating ethanol reinforcement. This is due to both a lack of high-affinity and selective ligands capable of discriminating among the $\mathrm{GABA}_{\mathrm{A}}$ receptor subunits and the heterogeneity 
of various subunits within the known alcohol reward circuitry. ${ }^{31,34}$ Of the potential GABA $_{\mathrm{A}}$ receptors involved in the reinforcing properties of alcohol, evidence suggests the $\alpha 1$ subtype within the VP may play an important role in regulating alcohol-seeking behaviors, as mentioned above. The VP contains one of the highest distributions of $\alpha 1$ subunits in the mesolimbic system. ${ }^{32-35}$ Finally, acute ethanol administration has been reported to selectively enhance the effects of iontophoretically applied GABA in the VP. These effects correlate highly with $\left[{ }^{3} \mathrm{H}\right]$ zolpidem binding (an a1-subtype selective agonist) ${ }^{19,20}$ Together, the above findings suggest a possible role for the VP $\alpha_{1} 1$ receptors in the reinforcing properties of alcohol.

The $\mathrm{GABA}_{\mathrm{A}}$ receptor is the major inhibitory neurotransmitter receptor of the central nervous system (CNS) and the site of action of a variety of pharmacologically and clinically important drugs, such as benzodiazepines, barbiturates, neuroactive steroids, anesthetics and convulsants. ${ }^{45}$ It is now clear that these receptors regulate the excitability of the brain, anxiety, muscle tone, circadian rhythms, sleep, vigilance, memory, and learning. ${ }^{45}$ There are several disease states associated with the improper functioning of this protein, including anxiety, epilepsy, ${ }^{46}$ insomnia, ${ }^{47}$ depression and bipolar disorder, ${ }^{48,}$ ${ }^{49}$ schizophrenia, ${ }^{50}$ as well as mild cognitive impairment and Alzheimer's disease. ${ }^{51}$ A role of GABA

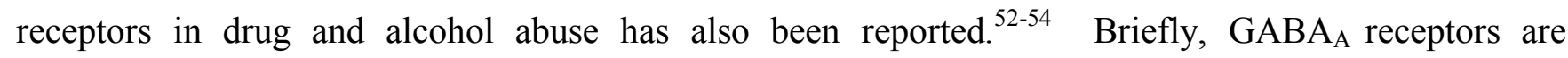
composed of 5 subunits that form a central chloride channel and can belong to different subunit classes. 
A total of 19 subunits $(6 \alpha, 3 \beta, 3 \gamma, 1 \varepsilon, 1 \pi, 1 \theta, 3 \rho)$ of the $\mathrm{GABA}_{\mathrm{A}}$ receptor have been cloned and sequenced from the mammalian nervous system. ${ }^{55,56}$ All these polypeptides possess an approximate molecular mass of $\sim 50 \mathrm{kD}$ and are structurally related.

The existence of multiple $\mathrm{GABA}_{\mathrm{A}}$ receptor subunits can give rise to a large number of different GABA $_{\mathrm{A}}$ receptor subtypes. ${ }^{57}$ The majority of $\mathrm{GABA}_{\mathrm{A}}$ receptors, however, are composed of $1 \gamma$ and $2 \alpha$ and $2 \beta$ subunits. The presence of a $\gamma$ subunit within a GABA $_{A}$ receptor is necessary for the formation of a benzodiazepine binding site that is located at the interface of an $\alpha$ and $\gamma$ subunit. Whereas the classical benzodiazepines, such as diazepam or flunitrazepam, exhibit a high affinity for receptors composed of $\alpha 1 \beta \gamma 2, \alpha 1 \beta \gamma 2, \alpha 3 \beta \gamma 2$, or $\alpha 5 \beta \gamma 2$ subunits (diazepam sensitive (DS) receptors), as well as for their less intensively investigated analogues containing the $\gamma 3$ subunit, other benzodiazepine binding site ligands are also able to interact with $\alpha 4 \beta \gamma 2$ or $\alpha 6 \beta \gamma 2$ receptors (diazepam insensitive (DI) receptors), or with receptors containing $\gamma 1$ subunits. $^{45}$ Receptors containing $\gamma 1$ or $\gamma 3$ subunits exhibit quite a low abundance in the brain ${ }^{58-60}$ and their contribution to the "in vivo" effects of benzodiazepine binding site (BZ BS) ligands currently is unclear.

To evaluate the role of the $\alpha 1$ receptor in regulating alcohol reinforcement, 3-propoxy- $\beta$ carboline hydrochloride (3-PBC), a mixed benzodiazepine (BDZ) agonist-antagonist with binding selectivity at the $\alpha 1$ receptor was developed. ${ }^{2}$ Compared with the prototype BDZ agonist zolpidem, 3- 
PBC exhibits a slightly higher binding selectivity for the $\alpha 1$ receptor ${ }^{61,62}$ Preliminary behavioral

studies in several species (e.g., rats, mice, and primates) show that 3-PBC is a BDZ antagonist, exhibiting competitive binding-site interactions with BDZ agonists at low to moderate doses (2.5-15 $\mathrm{mg} / \mathrm{kg}){ }^{61,63,64}$ At higher doses $(15-60 \mathrm{mg} / \mathrm{kg}), 3-\mathrm{PBC}$ produces anxiolytic effects in the plus maze that are comparable with those of chlordiazepoxide. ${ }^{63}$ Hence, 3-PBC displays an agonist or antagonist profile depending on both the dose and the task employed. To determine the capacity of 3-PBC to modulate physiological GABAergic effects, 3-PBC was evaluated in recombinant $\alpha 1, \alpha 2, \alpha 3, \alpha 4$ and $\alpha 5$ receptors. Next, it was determined whether the in vitro binding affinity of 3 PBC in wild-type synaptosomal cortical membranes would mimic the actions of 3-PBC at recombinant $\alpha 1$ receptors. In addition the in vivo capacity of 3-PBC to selectively reduce alcohol-maintained responding in a rodent model of the human condition of alcohol abuse after systemic and intra-VP infusions was determined. ${ }^{22,65}$

The evidence suggests both a regional and receptor subtype specificity for $\mathrm{GABA}_{\mathrm{A}}$-containing receptors in regulating alcohol-motivated behaviors. ${ }^{66}$ Specifically, the $\alpha 1$ subtype in the anterior and medial $\mathrm{VP}^{2}$ and the $\alpha 5$ isoform in the CA1 CA3 hippocampus ${ }^{22}$ have both been shown to be important mediators of alcohol reinforcement. Unlike the VP and hippocampus, unequivocal research exists on the primary type of isoform within the CeA. For example, while some investigators contend that the 
CeA is comprised primarily of receptors of the $\alpha 1$ subtype, ${ }^{67}$ others suggest the $\alpha 2$ and $\alpha 3$ receptors are the most predominant isoforms. ${ }^{31,32,34}$ Thus given the proposed subunit composition of the GABA receptors within the CeA, pharmacological compounds capable of exploiting the $\alpha 1$, $\alpha 2$, and $\alpha 3$ subunit-containing $\mathrm{GABA}_{\mathrm{A}}$ receptors represent optimal tools to evaluate the role of the $\mathrm{GABA}_{\mathrm{A}}$ receptors in alcohol reinforcement and better understand neurobehavior and ethanol responding. a1 Subtype Selective Ligands

The $\beta$-carboline-3-carboxylate-t-butyl ester $(\beta \operatorname{cct})$ is a mixed benzodiazepine agonist- antagonist ligand with binding selectivity at the $\alpha 1$ receptors, ${ }^{2,63,68} \beta \mathrm{cct}$ also exhibits some affinity (albeit lower) for both the $\alpha 2$ and $\alpha 3$ receptors. Behavioural studies in several species (eg, rats, mice, primates) show that $\beta$ cct is a BDZ antagonist exhibiting competitive binding site interaction with BDZ agonists over a broad range of doses. ${ }^{61,63,69-73}$ Other studies show that $\beta$ cet produces anxiolytic effects in rodents ${ }^{63}$ and potentiates the anticonflict response induced by $\alpha 1$ subtype agonists in primates. ${ }^{71}$ Thus, $\beta c c t$ displays a weak agonist or antagonist profile depending on the behavioral task, species, and dose employed.

In studies involving the $\alpha 1$ subtype, $\beta C C T$ and $3-\mathrm{PBC}$ were observed to selectively reduce alcohol-motivated behaviors in a variety of experiments. ${ }^{2,74}$ However, unlike the $\alpha 5$ selective inverse agonist RY-23, both the $\beta$-carboline antagonists $\beta C C T$ and 3-PBC displayed mixed weak agonistantagonist profiles in vivo in alcohol $\mathrm{P}$ and $\mathrm{HAD}$ rats. Therefore, in addition to being able to study the 
molecular basis of alcohol reinforcement, $\alpha 1 \mathrm{Bz}$ beta-carboline ligands which display mixed agonistantagonist pharmacology in alcohol P and HAD rats may be capable of reducing alcohol intake while eliminating or greatly reducing the anxiety associated with habitual alcohol, abstinence or detoxification. Thus, these types of ligands may be ideal clinical agents for the treatment of alcohol dependent individuals. ${ }^{2,74}$

Consequently, several series of structurally different compounds have been synthesized which possess some $\alpha_{1}$ subtype selectivity. ${ }^{75-79}$ The discovery of high affinity, saturable, and stereospecific ligands for $\mathrm{BzR}$ has been coupled with the demonstration that $\beta$-carbolines exhibited an affinity for the BzR ${ }^{80-87}$ Some of these agents act on the BzR to induce effects that are functionally opposite (inverse agonists/antagonists) to those of classical BDZs. Consequently, the affinities of a wide variety of $\beta$ carbolines have been reported in synaptosomal membranes from this laboratory, ${ }^{80,82,83,88-94}$ and the laboratories of others, ${ }^{95-100}$ and this prompted the study of the binding affinities of a series of $\beta$ carbolines $^{75}$ at 5 recombinant $\mathrm{GABA}_{\mathrm{A}} / \mathrm{BzR}$ subtypes $\left(\alpha_{1} \beta_{3} \gamma_{2}, \alpha_{2} \beta_{3} \gamma_{2}, \alpha_{3} \beta_{3} \gamma_{2}, \alpha_{5} \beta_{3} \gamma_{2}\right.$ and $\left.\alpha_{6} \beta_{3} \gamma_{2}\right)$ expressed from recombinant human cell lines. ${ }^{95,101,102}$ In general, this series of $\beta$-carboline ligands exhibited some selectivity at $\alpha_{1}$ receptor subtypes including $\beta C C t$ (1) and 3-PBC (2). ${ }^{2,} 3$ These two ligands displayed a 20-fold and 10-fold selectivity, respectively, for the $\alpha_{1}$ subtype over the $\alpha_{2}$ and $\alpha_{3}$ receptors, as well as over 150 -fold selectivity for the $\alpha_{1}$ site over the $\alpha_{5}$ subtype. ${ }^{2,3} \beta \mathrm{CCt}$ (1) was more selective at the $\alpha_{1}$ subtype in vitro than the classical $\alpha_{1}$ selective agonists zolpidem (3) and CL 218872 (4) (Figure 1). ${ }^{88,103,104}$ A number of in vitroand in vivo studies employing $\alpha_{1}$ (e.g., zolpidem ,CL 218872, ${ }^{105} \beta C \mathrm{Ct}$, and 3 -PBC ${ }^{106}$ ) selective ligands suggest the $\alpha_{1}$-containing $\mathrm{GABA}_{\mathrm{A}} / \mathrm{Bz}$ receptors of the ventral pallidum (VP) play an important role in regulating alcohol's neurobehavioral effects; particularly alcohol's reinforcing properties. $2,106,20,35,107$ 


\section{Structure Activity Relationships:}

A predictive 3-D QSAR pharmacophore/receptor model for inverse agonist/antagonist $\beta$ carbolines was initially developed via Comparative Molecular Field Analysis (CoMFA) and later refined. ${ }^{108,109}$ Affinities of ligands from 15 different structural classes have been evaluated. ${ }^{110}$ Based on this CoMFA study of a series of $\beta$-carbolines, Huang et al. reported that $\beta$-carbolines bind to all diazepam sensitive (DS) sites of the BzR with some selectivity at the $\alpha_{1}$ containing receptor isoform and this was confirmed by in vitro binding affinity of these ligands. ${ }^{111}$ A lipophilic region $\left(\mathrm{L}_{\mathrm{Di}}\right)$ of the pharmacophore receptor model appears to be larger in the $\alpha_{1}, \alpha_{2}$ and $\alpha_{3}$-containing receptor isoforms and important for $\alpha_{1}$ subtype selectivity. ${ }^{110}$ More recently, during the design and synthesis of $\beta C C t-$ related bivalent ligands, ${ }^{112-115}$ it was found that a series of 3,6-disubstituted $\beta$-carbolines (see Figure 1), including 6-iodo- $\beta C C t$ (5) and 6-trimethylsilanyl-ethynyl- $\beta C C t$ (6) (Figure 1) possessed $\alpha_{1}$ subtype selectivity. ${ }^{112}$

Figure 1. In vitro binding affinities of a series of $\alpha_{1}$ selective ligands $\left(\mathrm{K}_{\mathrm{i}}\right.$ in $\left.\mathrm{nM}\right)$. 
<smiles>CC(C)(C)OC(=O)c1cc2c(cn1)[nH]c1ccccc12</smiles>

$1 \beta \mathrm{CCt}$

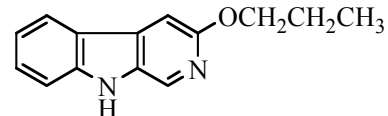

2 3PBC

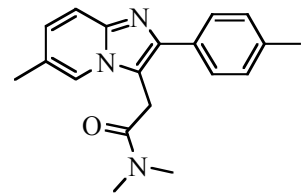

3 zolpidem

$\begin{array}{ccccccccccccccc}\alpha_{1} & \alpha_{2} & \alpha_{3} & \alpha_{5} & \alpha_{6} & \alpha_{1} & \alpha_{2} & \alpha_{3} & \alpha_{5} & \alpha_{6} & \alpha_{1} & \alpha_{2} & \alpha_{3} & \alpha_{5} & \alpha_{6} \\ 0.72 & 15 & 18.9 & 110.8 & >5,000 & 5.3 & 52.3 & 68.8 & 591 & >1000 & 26.7 & 156 & 383 & >10,000 & >10,000\end{array}$<smiles>Cc1n[nH]c(/C=C\C(=N)c2cccc(C(F)(F)F)c2)n1</smiles>

4 CL 218872

$\begin{array}{lllll}\alpha_{1} & \alpha_{2} & \alpha_{3} & \alpha_{5} & \alpha_{6}\end{array}$

$\begin{array}{lllll}57 & 1964 & 1161 & 561 & >10,000\end{array}$<smiles>C#Cc1ccc2[nH]c3cnc(C(=O)OC(C)(C)C)cc3c2c1</smiles>

7 WYS8 (6-ethynyl- $\beta C C t$ )

$\begin{array}{ccccc}\alpha_{1} & \alpha_{2} & \alpha_{3} & \alpha_{5} & \alpha_{6}\end{array}$

$\begin{array}{lllll}0.972 & 111 & 102 & 1473 & 1980\end{array}$

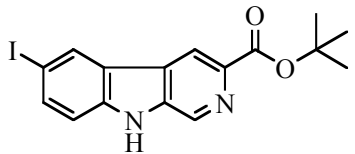

5 6- iodo- $\beta \mathrm{CCt}$

$\begin{array}{lllll}\alpha_{1} & \alpha_{2} & \alpha_{3} & \alpha_{5} & \alpha_{6}\end{array}$

$\begin{array}{lllll}14.4 & 44.9 & 123 & 65.3 & >4000\end{array}$

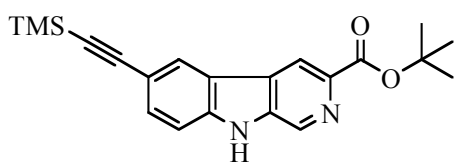

6 6-trimethylsilanylethynyl- $\beta \mathrm{CCt}$

$\begin{array}{lllll}6.8 & 30 & 36 & 108 & 1000\end{array}$

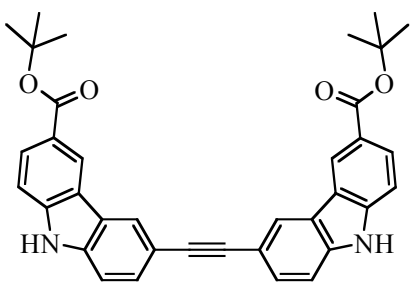

$31 \beta C C t$ bivalent ligand

$\begin{array}{ccccc}\alpha_{1} & \alpha_{2} & \alpha_{3} & \alpha_{5} & \alpha_{6} \\ 30 & 124 & 100 & >300 & >4000\end{array}$

The rigidly linked linear bivalent ligands of $\beta \mathrm{CCt}$ at position "6" did bind to BzR receptors with some $\alpha_{1}$ subtype selectivity and may provide the desired $\alpha_{1}$ selectivity through specific occupation of the $L_{D i}$ region of the pharmacophore/receptor model. ${ }^{112}$ Although the two 3,6-disubstituted- $\beta$-carbolines 5 and 6 are less potent than $\beta C C t(\mathbf{1})$, the potent binding affinities observed for $\mathbf{5}$ and $\mathbf{6}$ at the $\alpha_{1}$ subtype has stimulated the synthesis of the $\beta C C t$ analogs: 3 -substituted- $\beta$-carbolines as well as 3,6 -disubstituted- $\beta$ carbolines.

On the other hand, these studies also indicated that the selectivity of $\mathrm{GABA}_{\mathrm{A}} / \mathrm{BzR}$ site ligands 
could be described in relation to binding and physiological efficacy in vitro. The physiological efficacy was based on the capacity of a ligand to modulate GABAergic function. ${ }^{116}$ BzR ligands act on chloride flux over a continuum from positive to negative modulation, with antagonists acting theoretically, at a point on the continuum, with zero intrinsic efficacy (bind to a receptor but exhibit no action). ${ }^{76}$ Consequently, the pharmacological profiles of $\beta C C t$ and 3-PBC at recombinant $\alpha_{1} \beta_{3} \gamma_{2}, \alpha_{2} \beta_{3} \gamma_{2}$, $\alpha_{3} \beta_{3} \gamma_{2}, \alpha_{4} \beta_{3} \gamma_{2}, \alpha_{5} \beta_{3} \gamma_{2}$ and $\alpha_{6} \beta_{3} \gamma_{2}$ receptor subtypes expressed in Xenopus oocytes were investigated. ${ }^{2,3,65}$

Figure 2. Efficacy of $\beta C C t$ in modulating $\mathrm{GABA}$ at recombinant $\mathrm{GABA}_{a 1-\alpha 5}$ receptors

in Xenopus oocytes: comparison with other BzR antagonists.

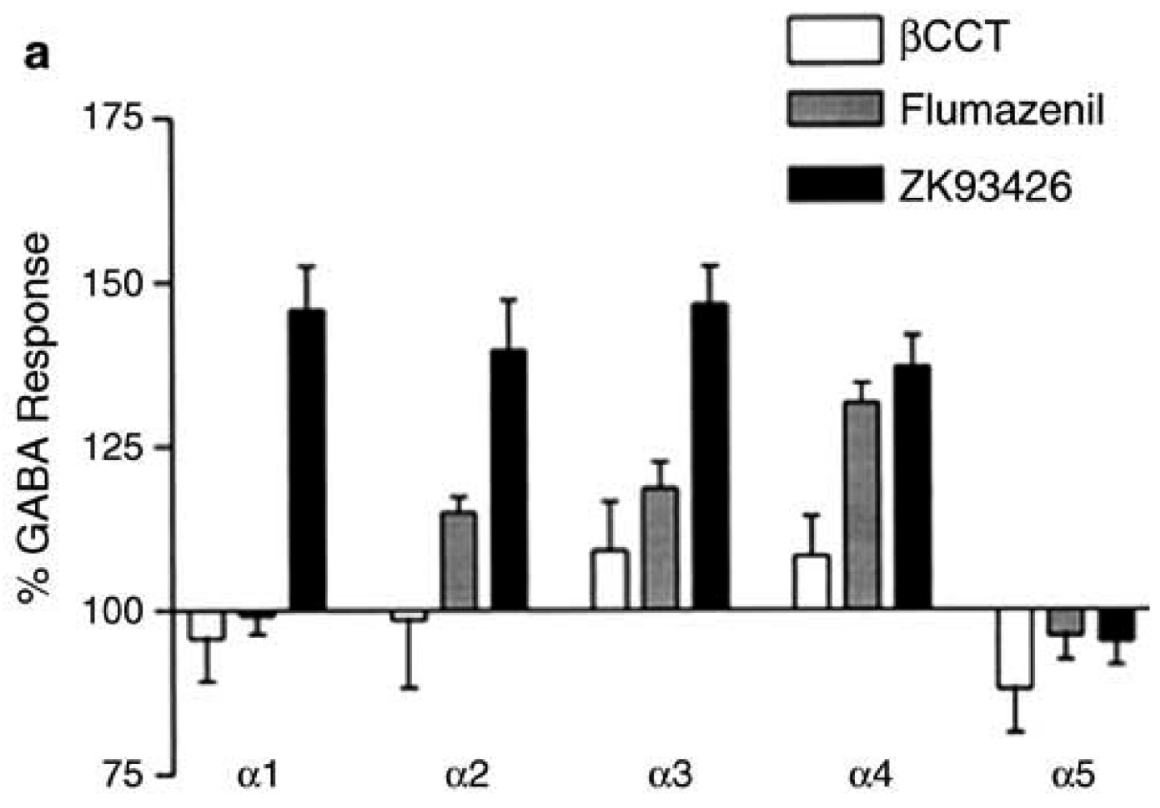

Modulation of GABA ${ }_{A} \alpha_{1} \beta_{3} \gamma_{2}, \alpha_{2} \beta_{3} \gamma_{2}, \alpha_{3} \beta_{3} \gamma_{2}, \alpha_{4} \beta_{3} \gamma_{2}$ and $\alpha_{5} \beta_{3} \gamma_{2}$ receptor subunit combinations expressed in Xenopus oocytes by $\beta \mathrm{CCt}$ (open bars), flumazenil (shaded bars), and ZK 93426 (black bars). A saturating concentration (1-10 $\mu \mathrm{M})$ was coapplied over voltage-clamped oocytes along with an $\mathrm{EC}_{50}$ of GABA.

The results of this study illustrated that $\beta \mathrm{CCt}$ was a near "neutral" antagonist (i.e., little or no efficacy) at all receptor subtypes. In fact, the level of intrinsic efficacy of $\beta C C t$ in oocytes was less at 
some receptor subtypes than the classical nonselective antagonist flumazenil (Ro 15-1788, for which intrinsic efficacy at all BZ-sensitive $\mathrm{GABA}_{\mathrm{A}}$ subtype was relatively low, but not zero). To date, no compound has been characterized that exhibits zero efficacy at all BzR subtypes, raising the possibility that a compound labeled as an "antagonist" may indeed exhibit functional activity given the right circumstances. For example, more recently, the efficacies of both $\beta C C t$ and 3 -PBC in the selective reduction of alcohol responding and production of anxiolytic effects were demonstrated in $\mathrm{P}$ and HAD rats following oral administration. ${ }^{117}$ When compared with the classical Naltrexone treatment, these reductions in alcohol responding were more selective and longer in duration. ${ }^{117}$ It is important to note that similar reductions with $\beta C C$ t and $3-\mathrm{PBC}$ have now also been reported in primates by our collaborators, Drs Elise Weerts from John Hopkins and Donna Platt from Harvard Medical School (unpublished results). These studies in primates were initially investigated based on the original studies in the alcoholic rats. In summary, the antagonist $\beta C C t$ exhibited either a neutral or low-efficacy agonist response at GABA receptors in oocytes. Although there has been some debate in the literature at present as to whether a ligand's binding or efficacy selectivity was "the more salient factor" in determining a ligand's capacity to function as an alcohol antagonist, ${ }^{3,75,117}$ the knowledge of the efficacy of an individual putative anti-alcohol reward ligand across all $\mathrm{GABA}_{\mathrm{A}}$ receptors was indeed critical to the knowledge of their mode of action in the CNS.

Based on the limited availability of data on the series of $\alpha_{1}$ "binding" and "efficacy" selective $\beta$ carbolines $(\beta C C t, 3 \mathrm{PBC})$ as anti-alcohol agents ${ }^{118}$ the present study was designed to expand the SAR and search for better $\alpha_{1}$ subtype selective ligands. These compounds may be promising modulators of alcohol-related co-morbid behaviors in alcohol dependence via the $\mathrm{GABA}_{\mathrm{A}} / \mathrm{BzR}$ system. Although recent evidence suggests a salient role for GABAergic mechanisms in the regulation of excessive alcohol drinking and the negative affective states associated with abstinence, decreased GABAergic tone stemming from chronic alcohol use and withdrawal may serve to generate anxiety. ${ }^{119}$ Thus, compounds that enhance GABAergic tone may be effective and safe treatments for both excessive 
alcohol drinking and the negative affective states associated with abstinence and may represent novel pharmacotherapies to treat alcoholism.

In this regard, the chemistry and pharmacological evaluation of a series of structurally modified analogues of $\beta C C t(1)$ as selective and potent $\alpha_{1}$ subtype-preferring ligands are described. The synthesis of the $\alpha 1$ selective compound 7 (WYS8) and the structure-activity relationships (SAR) of 3,6disubstituted $\beta$-carbolines are also presented. The established pharmacophore/receptor model ${ }^{110,120}$ of BDZ binding sites was employed to design ligands with respect to the $\mathrm{L}_{\mathrm{Di}}$ region at position- 6 , as well as characterize the binding pocket $\mathrm{L}_{1}$ at position-3. Protein-ligand docking of the $\alpha 1$ subtype $\mathrm{GABA}_{\mathrm{A}}$ receptor protein and WYS8 illustrated the agreement between the pharmacophore/receptor model and BzR site prediction based on homology modeling. ${ }^{120-122}$

\section{Chemistry:}

The synthesis of the ligands under study is outlined in Schemes 1, 2 and 3. The important precursor $\beta$-carboline-3-carboxylate-ethyl ester ( $\beta C C E, 8)$ and its corresponding acid (9) were the intermediates required for large-scale synthesis of $\beta \mathrm{CCt}(\mathbf{1})$, as well as an intermediate required for the synthesis of the new $\beta$-carbolines. As outlined in Scheme 1, DL tryptophan 10 was converted into tetrahydro- $\beta$-carboline (11) via a Pictet-Spengler reaction. Fischer esterification of 11, followed by oxidation with activated $\mathrm{MnO}_{2}$ provided the intermediate BCCE (8) on 200 gram scale. Hydrolysis of ester $\mathbf{8}$ to provide the acid $\mathbf{9}$, was then followed by esterification in $t$-butanol with CDI to provide BCCt (1). The synthesis of 3PBC·HCl (1) was more difficult to scale up due to the complex last step $(\mathbf{1 4} \rightarrow \mathbf{2})$. 
It began with $\beta C C E$ (8) from Scheme 1, which was heated with hydrazine to furnish hydrazide (13) in $82 \%$ yield. The hydrazide (13) was stirred with nitrous acid to provide an azide, which was unstable, and was converted into 3-amino- $\beta$-carboline (14) when stirred with acetic acid (Scheme 1) via a Curtius rearrangement. The last step, originally developed on a $100 \mathrm{mg}$ scale, has now been scaled up to 4 gram levels to furnish 3PBC hydrochloride salt in reasonable yield.

In Scheme 2, the $\beta$-carboline alkyl esters 16-20 as well as chiral $\beta C C t$ analogs 21-24, and 25, 26 were prepared via the CDI-mediated process described above (see Scheme I). ${ }^{123}$ Briefly, when $\beta$ carboline-3-carboxylic acid 9 was treated with 1,1-carbonydiimidazole (CDI) in dry DMF, the imidazole derivative 27 which resulted was subsequently transformed into the desired esters by treating it with the corresponding alcohols (individually) in the presence of DBU in a one-pot sequence. The key potential $\alpha_{1}$ chiral selective analogs CMD-30 R/S isomers $(21 \& \mathbf{2 2})$ can be synthesized by the CDI method in $90 \%$ yield (individually) on 10 gram scale. The required starting chiral alcohols were obtained by asymmetric reduction of the corresponding trifluoromethyl ketones with (+)-DIPchloride. ${ }^{124,125}$ or the (-)-DIP-enantiomer. The 6-substituted-iodo- $\beta$-carboline-3-carboxylates 28 were then prepared as intermediates to generate different functionality at position-6 through a palladiummediated cross coupling process. For example, as illustrated in Scheme 2, $\beta C \mathrm{Ct}(\mathbf{1})$ was treated with $\mathrm{I}_{2} / \mathrm{CF}_{3} \mathrm{COOAg}$ in chloroform to provide 6-iodo- $\beta \mathrm{CCt}$

Scheme 1. Large scale synthesis of $\beta C C t$ and synthesis of 3PBC. 


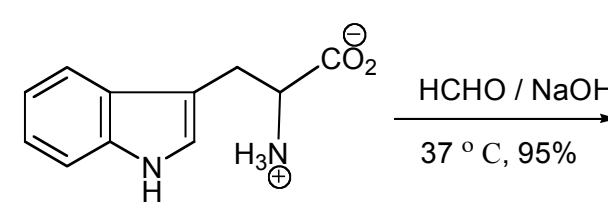

$10,1 \mathrm{~kg} / 22 \mathrm{~L}$

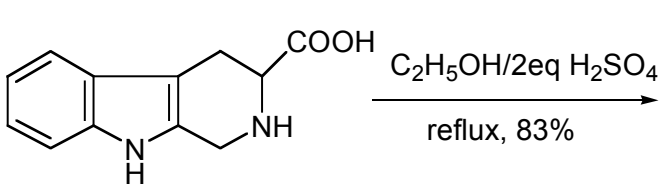

$11,500 \mathrm{~g} / 12 \mathrm{~L}$<smiles>CCOC(=O)C1Cc2c([nH]c3ccccc23)CN1</smiles>

$12,200 \mathrm{~g} / 12 \mathrm{~L}$ $\mathrm{MnO}_{2} /$ benzene reflux, $80 \%$ $1, \beta \operatorname{CCt} 5 \mathrm{~g}$

8, $\beta$ CCE $50 \mathrm{~g} / 1 \mathrm{~L}$<smiles>CCCOc1cc2c(c[n+]1Cl)[nH]c1ccccc12</smiles>

2, 3PBC

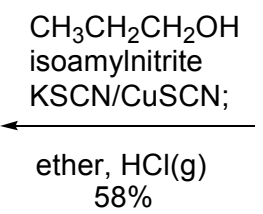

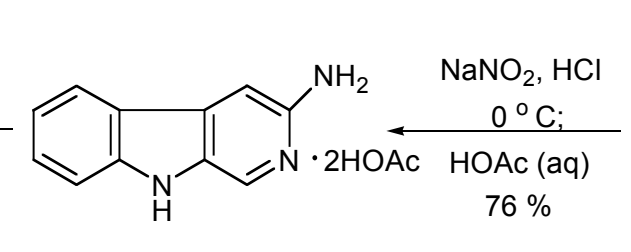

14
$\mathrm{NH}_{2} \mathrm{NH}_{2}$, EtOH reflux, $16 \mathrm{hr}$, $82 \%$<smiles>NNC(=O)c1cc2c(cn1)[nH]c1ccccc12</smiles>

13

5 (see also 28a) in 80\% yield and the 6-substituted targets 29-31 were obtained in 65\%-83\% yields via a Stille coupling process employing commercially available substituted tributyl-stannanes. The substitution by halogen occurred at position-6 via NMR analysis of 5 (or 28a) with One Dimensional Nuclear Overhauser Effect (NOE) experiments.

Depicted in Scheme 3 are the synthetic routes for the $\beta C C t$ related bivalent ligands 32 and $33 .{ }^{112}$ In order to efficiently affect a palladium mediated Sonogashira process at position- 6 of $\beta$-carbolines (a reactive electron-rich indole heterocycle), protection/deprotection of the indole $\mathrm{N}_{\mathrm{a}}-\mathrm{H}$ 
Scheme 2. CDI-mediated esterification of 3 -substituted $\beta$-carbolines followed by the conversion into 3,6-disubstituted $\beta$-carbolines.

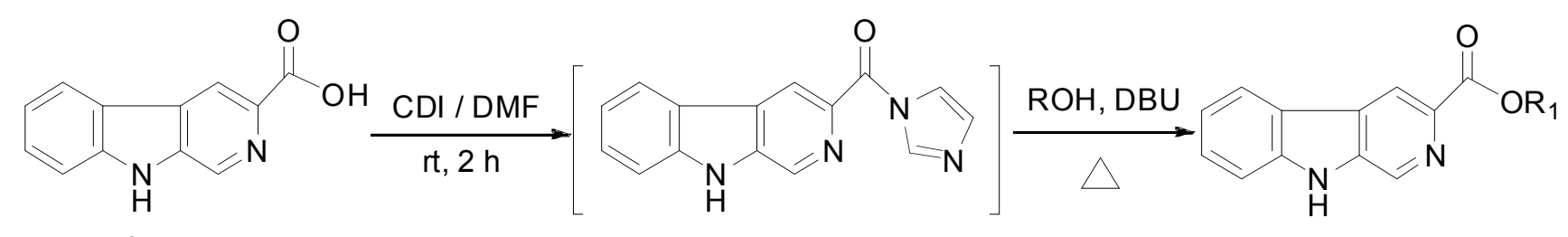

8

27

15, $\mathrm{R}_{1}=-\mathrm{CH}_{2} \mathrm{CF}_{3}$

16, $\mathrm{R}_{1}=-\mathrm{CH}\left(\mathrm{CF}_{3}\right)_{2}$

17, $\mathrm{R}_{1}=-\mathrm{CH}_{2} \mathrm{CCl}_{3}$

18, $\mathrm{R}_{1}=-\mathrm{CH}\left(\mathrm{CH}_{3}\right) \mathrm{CCl}_{3}$

19, $\mathrm{R}_{1}=-\mathrm{CH}\left(\mathrm{CH}_{2} \mathrm{CH}_{3}\right) \mathrm{CH}_{3}$

20, $\mathrm{R}_{1}=-\mathrm{CH}\left(\mathrm{CH}_{2} \mathrm{CH}_{3}\right) \mathrm{CF}_{3}$

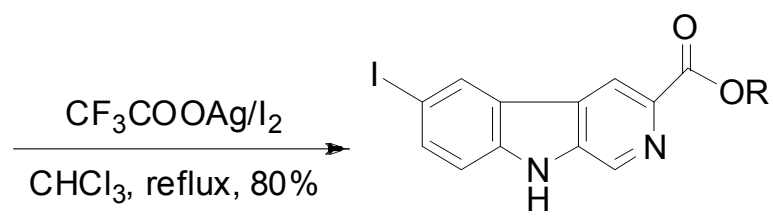

$$
\begin{aligned}
& \text { 5(28a), } \mathrm{R}_{1}=-\mathrm{C}\left(\mathrm{CH}_{3}\right)_{3}, \\
& \text { 28b, } \mathrm{R}_{1}=-\mathrm{CH}_{2} \mathrm{CF}_{3}, \\
& \text { 28c, } \mathrm{R}_{1}=-\mathrm{CH}_{2} \mathrm{CH}_{3}, \\
& \text { 28d, } \mathrm{R}_{1}=-\mathrm{CH}\left(\mathrm{CF}_{3}\right)_{2}
\end{aligned}
$$

24, $R_{1}=$

22, $\mathrm{R}_{1}=\mathrm{CF}^{\mathrm{CF}_{3}}$

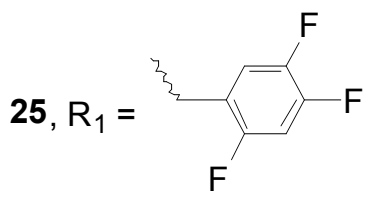

23, $R_{1}=m$

26, $\mathrm{R}_{1}=$

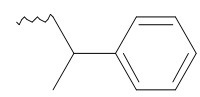

$\stackrel{\mathrm{C}}{\mathrm{F}}_{3}$

21, $\mathrm{R}_{1}=$ ,

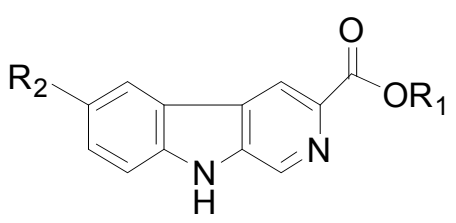

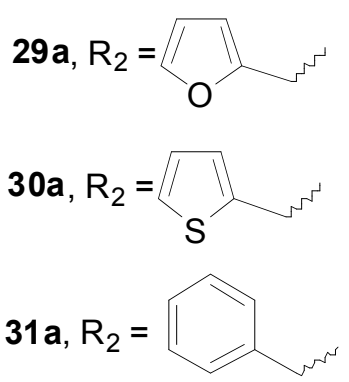

group in $\beta$-carbolines 34 and 35 was necessary. The Boc protected 6-ethynyl- $\beta$-carboline-3-carboxylic acid $t$-butyl ester (34) was prepared directly from 6-substituted acetylenyl $\beta C C t$ (7), which was initially termed WYS8. The common intermediate iodo- $\beta C C t 5$ (see also 28a) was then converted into the 6substituted trimethylsilylacetylenyl $\beta C C t(6)$ via a Sonogashira coupling process. ${ }^{126,127}$ At this point, 
TBAF was employed to remove the trimethylsilyl group to provide the 6-substituted acetylenyl $\beta C \mathrm{Ct}$ analog WYS8 (7) as well.

The ester 7, was then protected with a Boc group at the N(1) position to afford $\mathbf{3 4}$ under standard conditions. A Sonogashira process was then employed to couple 34 with Boc protected iodo- $\beta \mathrm{CCt}(\mathbf{3 5})$ to provide the rigid two carbon linked bivalent ligand 32 of $\beta \mathrm{CCt}$. The Boc protecting group was removed thermally by heating in cumene at high dilution and bivalent ligand $\mathbf{3 2}$ was obtained. The bisacetylenic bridged ligand 33 was synthesized from the Boc protected 6-ethynyl- $\beta C C t 34$ via a homocoupling process, ${ }^{128}$ followed by the removal of the Boc group under thermal conditions in cumene at high dilution.

Scheme 3. Preparation of 6-substituted acetylenyl $\beta C C t$ (7, WYS8) and related bivalent ligands.

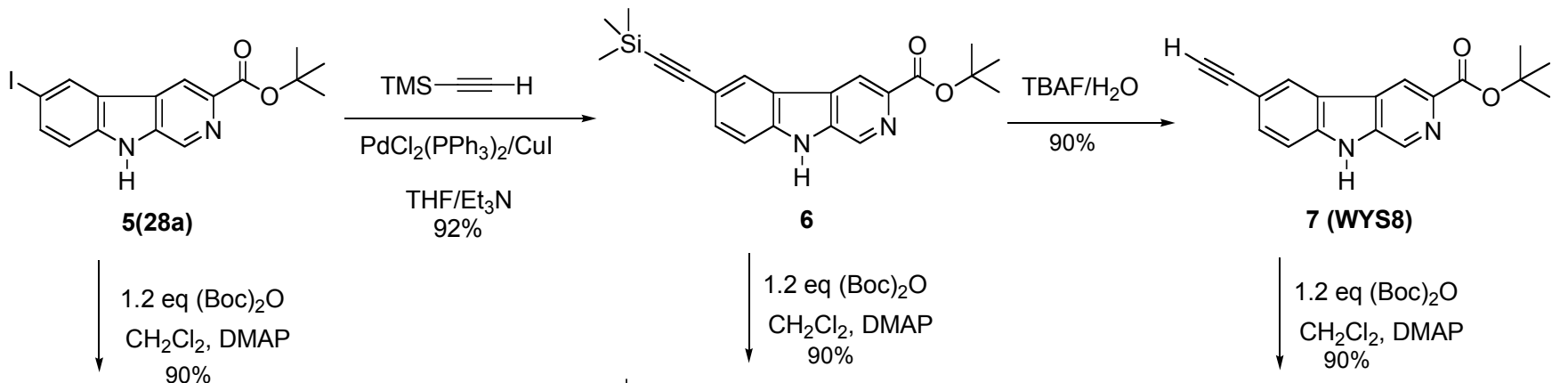

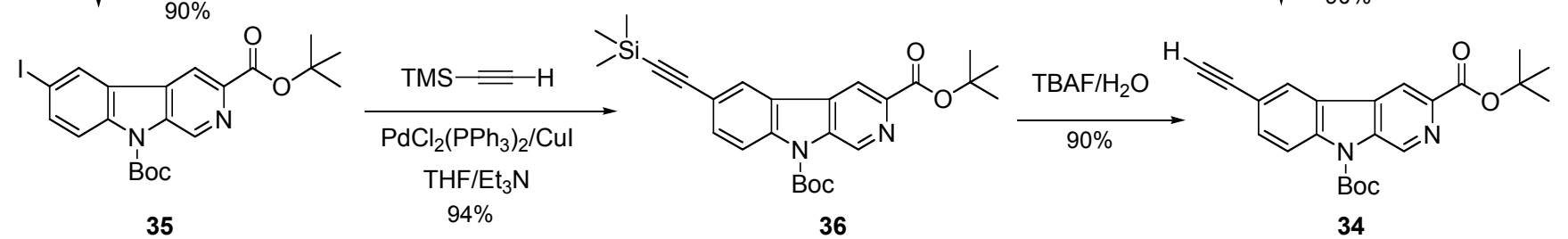
1) 34, $\mathrm{PdCl}_{2}\left(\mathrm{PPh}_{3}\right)_{2}, \mathrm{Cul}$, $\mathrm{THF} / \mathrm{Et}_{3} \mathrm{~N}$,

2) cumene, reflux
$80 \%$

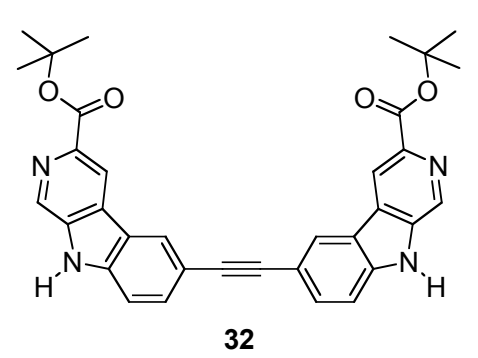

32
36

1) $\mathrm{PdCl}_{2}\left(\mathrm{PPh}_{3}\right)_{2}$, Cul, $\mathrm{BrCH}_{2} \mathrm{CO}_{2} \mathrm{Et}$, $\mathrm{THF} /(\mathrm{iPr})_{2} \mathrm{NH}, 60 \%$ 2) cumene, reflux

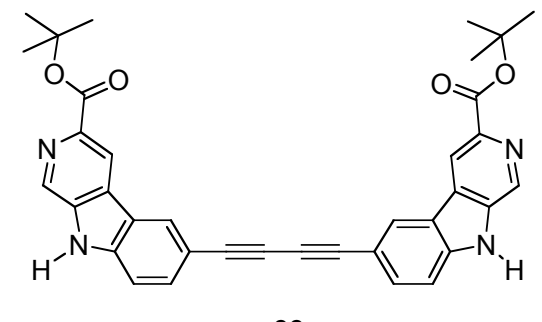

33 


\section{Biological \& Pharmacological Testing}

The affinity of compounds at $\mathrm{GABA}_{\mathrm{A}} / \mathrm{BzR}$ recombinant subtypes was measured by competition for $\left[{ }^{3} \mathrm{H}\right]$ Ro15-1788 (83 Ci/mmol; NEN) binding to Ltk- cell membranes expressing human receptors of composition $\alpha_{1} \beta_{3} \gamma_{2}, \alpha_{2} \beta_{3} \gamma_{2}, \alpha_{3} \beta_{3} \gamma_{2}, \alpha_{4} \beta_{3} \gamma_{2}, \alpha_{5} \beta_{3} \gamma_{2}$ and $\alpha_{6} \beta_{3} \gamma_{2}{ }^{95,101} \mathrm{~K}_{\mathrm{i}}$ values represent the mean of two determinations which differed by less than $10 \%$. The values are reported in $\mathrm{nM}$ and $1.8 \mathrm{nM}\left[{ }^{3} \mathrm{H}\right] \mathrm{Ro} 15-$ 1788 and $8 \mathrm{nM}\left[{ }^{3} \mathrm{H}\right]$ Ro $15-4513$ (for cells expressing $\alpha_{4} \beta_{3} \gamma_{2}$ and $\alpha_{6} \beta_{3} \gamma_{2}$ ) were used as radioligands. The results are summarized in Tables 1-3.

The electrophysiological analyses of all selective compounds were performed with whole cell variation of the patch-clamp-technique, in HEK cells employing GABA concentrations around the subtype-specific $\mathrm{EC}_{20}{ }^{129}$ to depict the quantitative efficacy difference [i.e., GABA modulation] and qualitative subunit modulation [i.e., subunit type] of these ligands relative to diazepam.

\section{Results and Discussion}

(1) $\beta$ CCt bivalent ligands. Although the $\alpha_{1} \beta_{3} \gamma_{2}$ BzR/GABAergic subtype is very similar in structure to the $\alpha_{2}$ and $\alpha_{3}$ subtypes, there are slight differences. ${ }^{110,130}$ One major difference is in region $\mathrm{L}_{\mathrm{Di}}$, which appears larger in the $\alpha_{1}$ subtype than in either the $\alpha_{2}$, or $\alpha_{3}$ or $\alpha_{5}$ subtypes. This is located near position -6 of $\beta C C t(\mathbf{1})$ and can be seen in the model of the Comparative Molecular Field Analysis (CoMFA) study for the $\alpha_{1}$ subtype (Figure 3). ${ }^{120,131}$ In particular, blue contours in the western region of the pharmacophore/receptor model imply positive lipophilic interactions in this area that corresponds to region $\mathrm{L}_{\mathrm{Di}}$ (a region in the pharmacophore adjacent to the extracellular domain of the receptor) of the unified pharmacophore/receptor model. In this region, bulky substituents are tolerated and occupation of this area with substituents appears to enhance affinity at $\alpha_{1}$ subtypes. This knowledge provided an opportunity to introduce a linker between two pharmacophoric $\beta$-carboline-3-carboxylate residues in order to design selective and rigid bivalent ligands. As described in the Introduction, initial efforts to 
find a novel series of $\alpha_{1}$-preferring ligands focused on design and synthesis of $\beta C C t$ bivalent ligands.

Although the $\alpha_{1}$ subtype selectivity was not amplified with the particular acetylenyl linked bivalent ligand 32, the ligand does bind preferentially at $\alpha_{1}$ subtypes (Table 1). It was proposed the two-carbon linker was not long enough and that crowding between the second $\beta \mathrm{CCt}$ unit and the receptor protein decreased the binding affinity at the $\alpha_{1}$ subtype, thereby negating some of the potential selectivity. However, these rigidly linked linear bivalent ligands $\mathbf{3 2}$ and $\mathbf{3 3}$ fit the $\mathrm{GABA}_{\mathrm{A}} / \mathrm{BzR}$ pharmacophore/receptor model very well (Figure 4). ${ }^{120}$ The unit at C-6, presumably, protrudes into the extracellular domain of the BzR, as previously expected, ${ }^{111,112}$ and bound to BzR with some $\alpha_{1}$ subtype selectivity. ${ }^{111,112}$ To our knowledge these are the first two bivalent ligands in the $\beta$-carboline series, which bind to BzR. Further pharmacological evaluation in vivo of the $\beta C C t$ bivalent ligand with the longer rigid linker should shed light on the above hypothesis and this would also provide some tools to determine the size and exact location of the $\mathrm{L}_{\mathrm{Di}}$ region.

Figure 3. Orthogonal views of CoMFA contour maps for the affinity of 6-benzyl-substituted $\beta$-carbolines at the $\alpha_{1} \beta_{3} \gamma_{2}$ BzR.

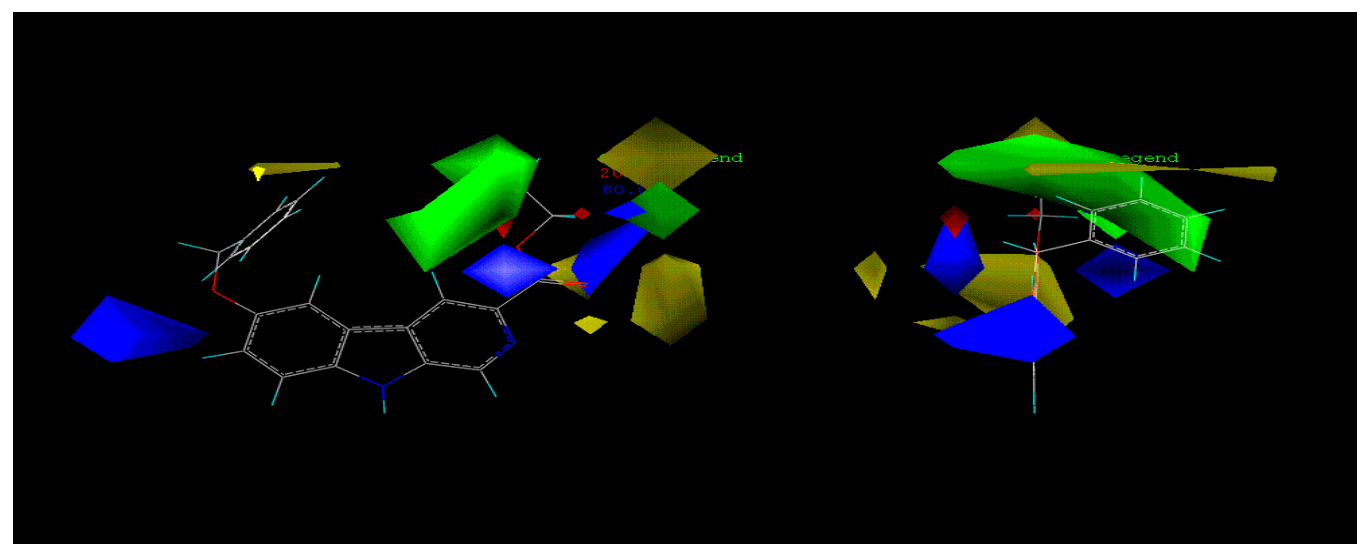

Orthogonal view of CoMFA contour maps for the $\alpha_{1} \beta_{3} \gamma_{2}$ receptor subtype with 6-benzyl-substituted $\beta$-carbolines modeled by Huang. ${ }^{88}$ Green contours represent areas of positive steric interaction at a contribution level of $85 \%$, which would result in reduced binding affinity. Blue contours represent areas of positive charge interaction at a level of $85 \%$, which would increase the affinity of a ligand. 
Figure 4. Alignment of bivalent ligands $\mathbf{3 2}$ and $\mathbf{3 3}$ within the included volume of the $\alpha_{1} \beta_{3} \gamma_{2}$ subtype.

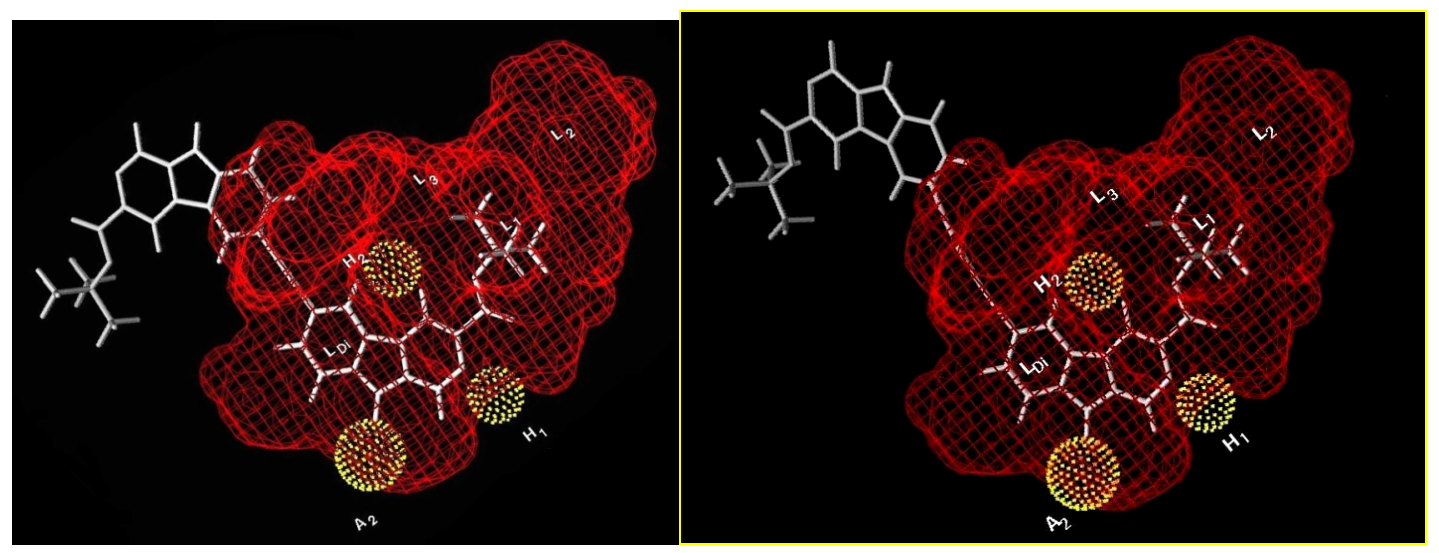

(2) WYS8. A series of 6-substituted- $\beta$-carboline-3-carboxylates have been synthesized and bound in vitro to the $\alpha_{1} \beta_{3} \gamma_{2}$ BzR subtype preferentially as compared to other subtypes (see Tables 13). ${ }^{110,111}$ These ligands have also been modeled in the $\mathrm{GABA}_{\mathrm{A}} / \mathrm{BzR}$ pharmacophore model, and the 6substitutents align well in the $\mathrm{L}_{\mathrm{Di}}$ region. ${ }^{132}$ Occupation of this region should lead to enhanced selectivity of a ligand at the $\alpha_{1}$ containing isoform. Among the new 3,6-disubstituted- $\beta$-carbolines, 6trimethylsilanylethnyl- $\beta C C t 6$ has been recently synthesized and found in vitro to prefer the $\alpha_{1}$ subtype. However, the most selective ligand for the $\alpha_{1}$ subtype was, to date, WYS8 (7). This $\alpha 1$ subtype selective ligand was 100 fold more selective over the other subtypes. This was the most $\alpha_{1}$ subtype selective ligand reported, to date, to these authors knowledge. This 6-substituted acetylenyl $\beta \mathrm{CCt} 7$ was 214 fold more selective for $\alpha_{1}$ isoforms over $\alpha_{5}$ isoforms. Studies of SAR in Table 1 confirmed the occupation of region $\mathrm{L}_{\mathrm{Di}}$ of the receptor pharmacophore model did enhance $\alpha_{1}$ selectivity in comparison to the affinity of the non-selective ligand diazepam or the $\alpha_{5}$ selective ligand, RY080. As illustrated in 
the two dimensional Figure 5, full occupation of the $\mathrm{L}_{\mathrm{Di}}$ lipophilic region by $\beta$-carbolines may account for the potency/selectivity of this class of ligands at the $\alpha_{1}$ subunit. Analysis of the in vitro binding data for this series of bulky 6-substituted $\beta$-carbolines (Table 1) has shown some selectivity for the $\alpha_{1}$ receptor subtype. In addition, it is important to note that binding affinity in this series of ligands of greater than $400 \mathrm{nM}$ usually results in zero efficacy at the subtype at pharmacologically relevant concentrations.

Homology models employed here of the $\mathrm{GABA}_{\mathrm{A}}$ receptor were as described previously ${ }^{121,133}$ except that a number of alternative models were considered for loop $\mathrm{C}$, which was two residues shorter than the template and hence built from a loop database. The final model was selected based on assessment of model quality ${ }^{134}$ and consistency with published mutational data, ${ }^{135-139}$ particularly with the T207 side-chain appropriately positioned facing the benzodiazepine-binding pocket. Positioning of WYS8 in the BzR was executed using a genetic algorithm (FlexiDock®). Flexible docking provides a means of docking ligands into protein active sites.

Figure 5a. Overlap of diazepam and $\beta C C t$ in the pharmacophore/receptor model. 

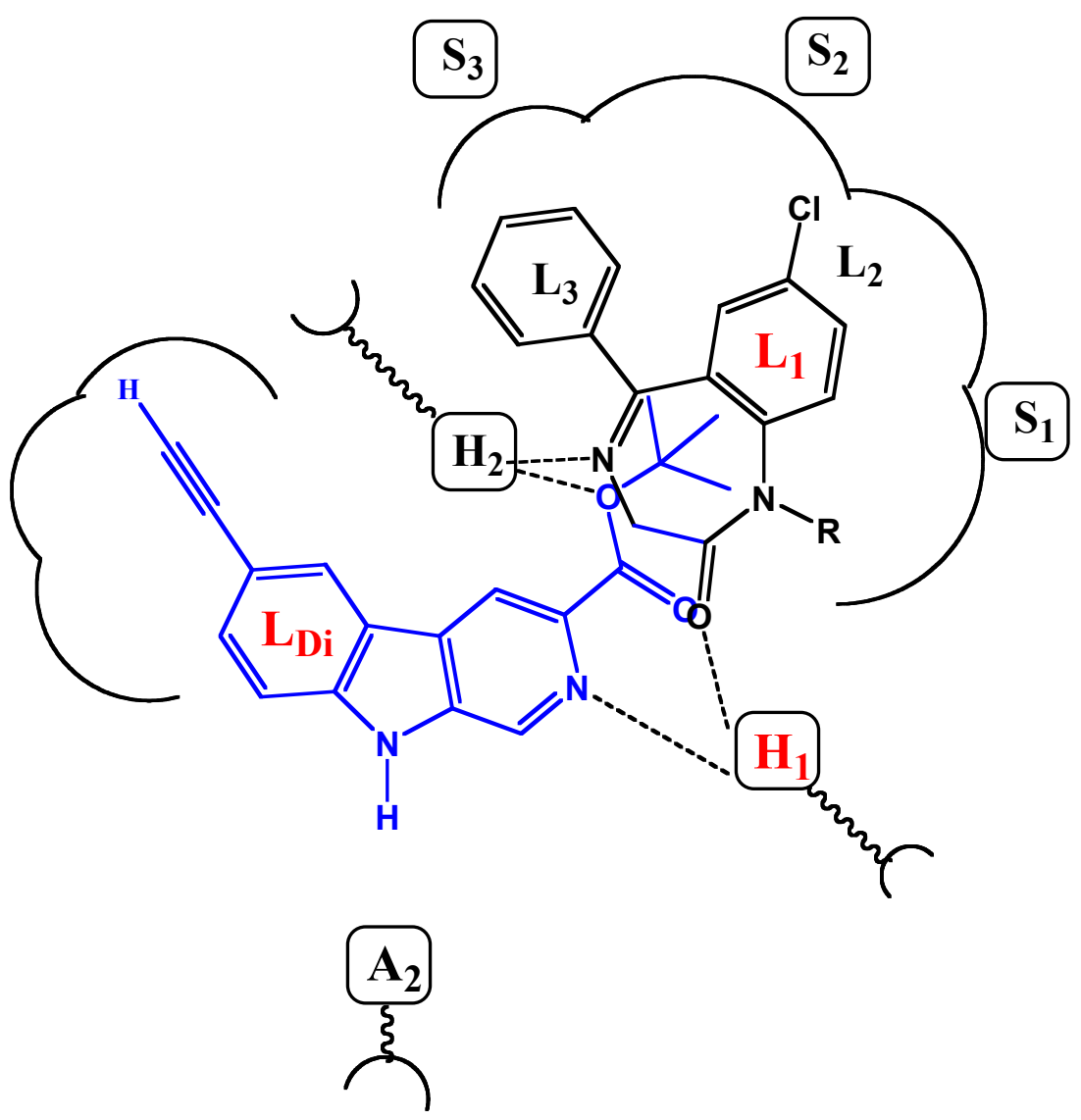

The structure of WYS8 and diazepam in a simple representation of the pharmacophore model. WYS8 (7) (blue line) and diazepam (black line) fitted to the inclusive pharmacophore model for the BzR. Sites $\mathrm{H}_{1}$ and $\mathrm{H}_{2}$ represent hydrogen bond donor sites on the receptor protein complex, while $\mathrm{A}_{2}$ represents a hydrogen bond acceptor site necessary for potent inverse activity in vivo. $\mathrm{L}_{1}, \mathrm{~L}_{2}, \mathrm{~L}_{3}$ and $\mathrm{L}_{\mathrm{Di}}$ are four lipophilic regions in the binding pharmacophore. Descriptors $\mathrm{S}_{1}, \mathrm{~S}_{2}$, and $\mathrm{S}_{3}$ are regions of negative steric repulsion.

Figure 5b. WYS8 docked in the BzR site of the $\alpha 1$ subtype $\mathrm{GABA}_{\mathrm{A}}$ receptor. The $\alpha 1$ and $\gamma 2$ subunits are rendered in yellow and blue, respectively. 


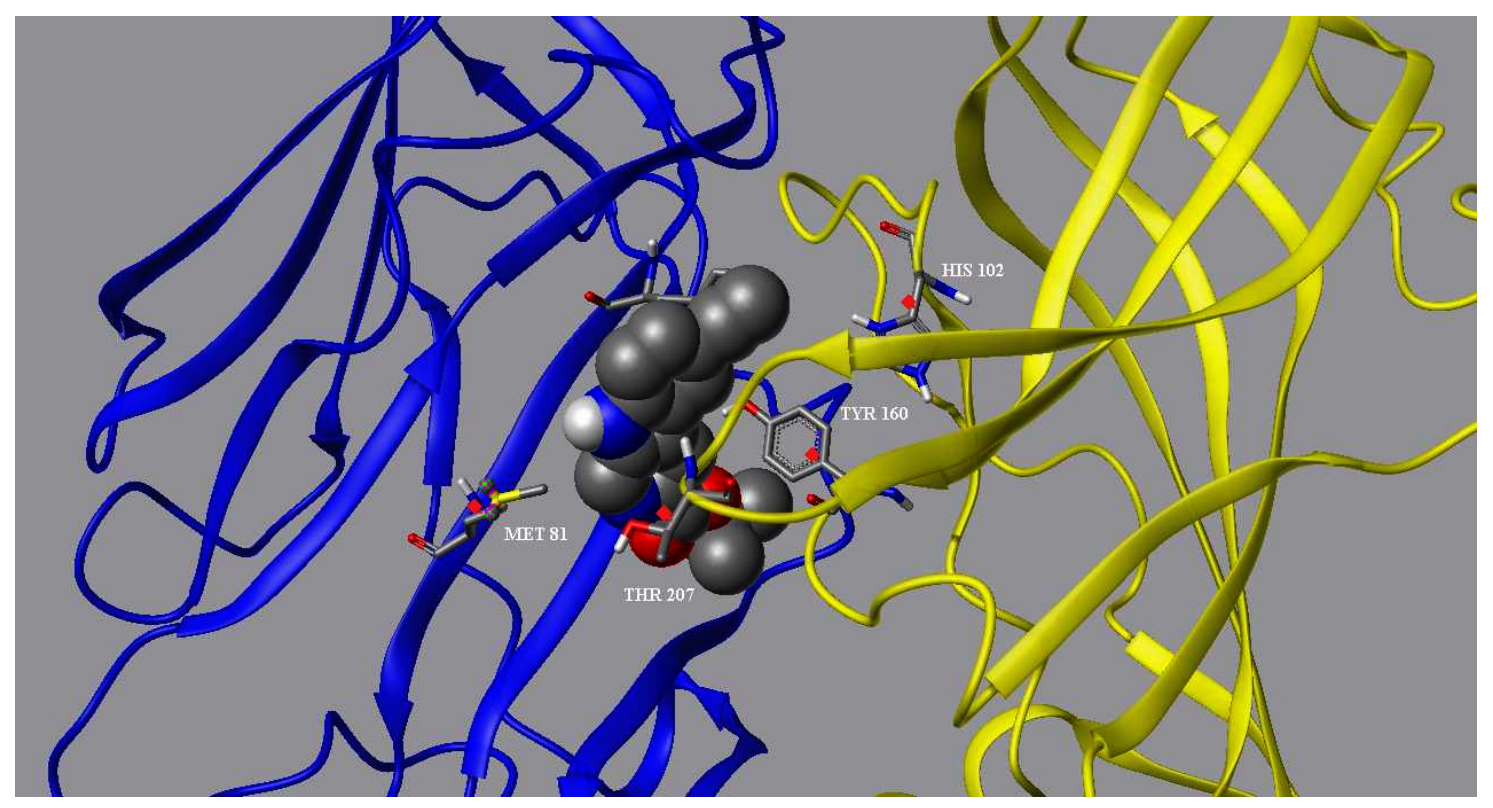

Table 1. Affinities $\left(\mathrm{K}_{\mathrm{i}}=\mathrm{nM}\right)$ of 3,6-disubstituted $\beta$-carbolines at $\alpha_{x} \beta_{2} \gamma_{2}(x=1-3,5,6)$ receptor subtypes.<smiles>[R]c1ccc2[nH]c3cnc([R3])cc3c2c1</smiles> 


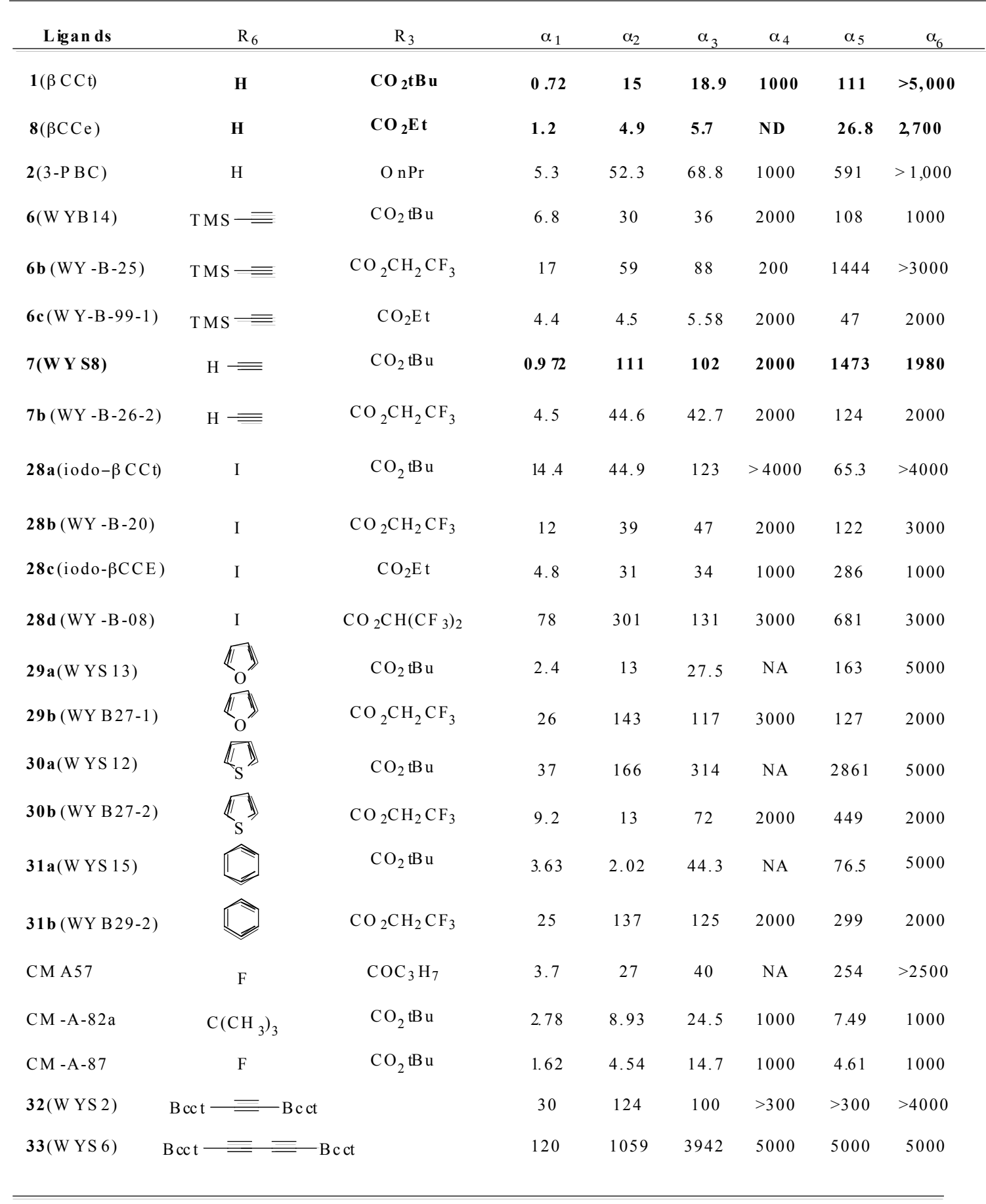

The affinity of compounds at $\mathrm{GABA}_{\mathrm{A}} / \mathrm{BzR}$ recombinant subtypes was measured by competition for $\left[{ }^{3} \mathrm{H}\right]$ flunitrazepam binding to HEK cell membranes expressing human receptors of composition $\alpha_{1} \beta_{2} \gamma_{2}, \alpha_{2} \beta_{2} \gamma_{2}, \alpha_{3} \beta_{2} \gamma_{2}, \alpha_{4} \beta_{2} \gamma_{2}, \alpha_{5} \beta_{2} \gamma_{2}$ and $\alpha_{6} \beta_{2} \gamma_{2}$. ${ }^{140}$

(3) 3-Substituted $\beta$-carbolines. It was initially believed by Braestrup, Loew, and others that an 
ester moiety at position-3 of $\beta$-carbolines was required for a ligand to exhibit high affinity binding at Bz binding sites. ${ }^{86,99,141,142}$ However, high affinity binding of $\beta$-carbolines including the antagonist 3propoxy $\beta$-carboline (3-P $\beta$ C, Table $2 b)$ demonstrated this was not the case ${ }^{83,92,93}$ Examination of data from additional studies ${ }^{80,92,93}$ have suggested that at least two factors affected high affinity binding at BzR with respect to 3 -alkoxy substituted $\beta$-carbolines, ${ }^{81,88,132,143}$ one of which was the lipophilicity of the substituent which interacted at $\mathrm{L}_{1}$. The $\mathrm{L} 1$ pocket tolerates linear groups up to 4 carbons in length. From ligands $\mathbf{1}$ and $\mathbf{6}$ it can be seen that binding affinity is lost, illustrating that the substituent at the 3position is to large to allow the ligand to bind. Likewise, the 3-benzyloxy $\beta$-carboline is also too bulky to fit the L1 pocket despite its lipophilic nature. The second factor was the ability of the substituent at position-3 to release electron density to the pyridine ring. This enhanced the basicity of the nitrogen atom at $\mathrm{N}(2)$ which resulted in a greater ligand-receptor interaction at $\mathrm{H}_{1}$. Analysis of the binding affinities of the novel trifluoroalkyl esters of $\beta$-carboline-3-carboxylic acid further supported this hypothesis (Table 2a). The trifluoroalkyl esters exhibited reduced binding affinity at all receptor subtypes when compared to their corresponding alkyl esters (20 vs. 19, 15 vs. $\beta C C E)$. Since the trifluoromethyl was a strong electron-withdrawing group, when compared to the corresponding alkoxycarbonyl moiety, the 3-trifluoroalkoxycarbonyl substituent would decrease electron density to the pyridine (N2) ring reducing the basicity of the nitrogen atom. This would result in a weaker ligandreceptor interaction at $\mathrm{H}_{1}$. In addition, the trifluoroalkyl group was less lipophilic than the corresponding alkyl moiety, which may result in a weaker interaction at $\mathrm{L}_{1}$. Ramachandran and Hanzawa have reported that trifluoromethyl groups are nearly as large as isopropyl or t-butyl functions. ${ }^{124,144}$ It was possible, the trifluoromethyl substituted ligands are simply too large to exert high affinity binding; however, $\beta$ CCT (1), WY-B-24 (25) and CM-A-77 (26) all bound with good potency to $\alpha 1$ BzR subtypes (see Tables 1 and 2), and these ester functions occupy a large molecular volume. 
Table 2a. Affinities $\left(\mathrm{K}_{\mathrm{i}}=\mathrm{nM}\right)$ of 3 -substituted $\beta$-carbolines at $\alpha_{\mathrm{x}} \beta_{2} \gamma_{2}(\mathrm{x}=1-3,5,6)$ receptor subtypes

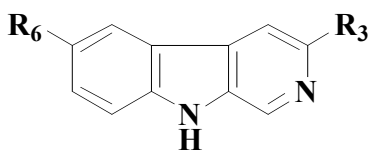

\begin{tabular}{|c|c|c|c|c|c|c|c|c|}
\hline Ligands & $\mathrm{R}_{6}$ & $\mathrm{R}_{3}$ & $\alpha_{1}$ & $\alpha_{2}$ & $\alpha_{3}$ & $\alpha_{4}$ & $\alpha_{5}$ & $\alpha_{6}$ \\
\hline BCCE & $\mathbf{H}$ & $\mathrm{CO}_{2} \mathrm{Et}$ & 1.2 & 4.9 & 5.7 & 1000 & 26.8 & 2700 \\
\hline 15 & $\mathrm{H}$ & $\mathrm{CO}_{2} \mathrm{CH}_{2} \mathrm{CF}_{3}$ & 3.0 & 24.5 & 41.7 & $>500$ & 125.7 & $>2000$ \\
\hline 16(WYB09-1) & $\mathrm{H}$ & $\mathrm{CO}_{2} \mathrm{CH}\left(\mathrm{CF}_{3}\right)_{2}$ & 3.99 & 8 & 32 & 1000 & 461 & 2000 \\
\hline 17(WYB23-1) & $\mathrm{H}$ & $\mathrm{CO}_{2} \mathrm{CH}_{2} \mathrm{CCl}_{3}$ & 10 & 33 & 43 & 1000 & 189 & 2000 \\
\hline 18(WYB17) & $\mathrm{H}$ & $\mathrm{CO}_{2} \mathrm{CH}\left(\mathrm{CH}_{3}\right) \mathrm{CCl}_{3}$ & 2000 & 2000 & 2000 & 3000 & 2000 & 5000 \\
\hline 19(CMA64) & $\mathrm{H}$ & $\mathrm{CO}_{2} \mathrm{CH}\left(\mathrm{CH}_{3}\right) \mathrm{C}_{2} \mathrm{H}_{5}$ & 18 & 60 & 116 & NA & 216 & $>2000$ \\
\hline 20(CMA69) & $\mathrm{H}$ & $\mathrm{CO}_{2} \mathrm{CH}\left(\mathrm{CF}_{3}\right) \mathrm{C}_{2} \mathrm{H}_{5}$ & 1000 & 1000 & 1000 & NA & 1000 & $>2000$ \\
\hline 25(WY-B-24) & & & 22.0 & 177 & 44.8 & 3000 & 422 & 3000 \\
\hline 26(CM-A-77) & & & 33.5 & 1000 & 1000 & 1000 & 1000 & 3000 \\
\hline
\end{tabular}

The affinity of compounds at $\mathrm{GABA}_{\AA} / \mathrm{BzR}$ recombinant subtypes was measured by competition for $\left[{ }^{3} \mathrm{H}\right]$ flunitrazepam binding to HEK cell membranes expressing human receptors of composition $\alpha_{1} \beta_{2} \gamma_{2}, \alpha_{2} \beta_{2} \gamma_{2}, \alpha_{3} \beta_{2} \gamma_{2}, \alpha_{4} \beta_{2} \gamma_{2}, \alpha_{5} \beta_{2} \gamma_{2}$ and $\alpha_{6} \beta_{2} \gamma_{2}{ }^{140}$

Table 2b. Affinities $\left(\mathrm{K}_{\mathrm{i}}=\mathrm{nM}\right)$ of Ether-substituted $\beta$-carbolines at $\alpha_{\mathrm{x}} \beta_{2} \gamma_{2}(\mathrm{x}=1-3,5,6)$ receptor subtypes 


\begin{tabular}{|c|c|c|c|c|c|}
\hline Ligands & $\alpha_{1}$ & $\alpha_{2}$ & $\alpha_{3}$ & $\alpha_{5}$ & $\alpha_{6}$ \\
\hline & 350.2 & 3000 & 3000 & 3000 & 10000 \\
\hline & 830 & 3000 & 3000 & 10000 & 10000 \\
\hline & 36.9 & 194 & 245 & 1000 & 1000 \\
\hline & 24.9 & 123.6 & 139.2 & 1000 & 10000 \\
\hline & 245 & 818 & 859 & 10000 & 10000 \\
\hline & 5.3 & 52.3 & 68.8 & 591 & 1000 \\
\hline & 6.43 & 25.1 & 28.2 & 826 & 1000 \\
\hline 40 & & & & & \\
\hline
\end{tabular}

The affinity of compounds at $\mathrm{GABA}_{\mathrm{A}} / \mathrm{BzR}$ recombinant subtypes was measured by competition for $\left[{ }^{3} \mathrm{H}\right]$ flunitrazepam binding to HEK cell membranes expressing human receptors of composition $\alpha_{1} \beta_{2} \gamma_{2}, \alpha_{2} \beta_{2} \gamma_{2}, \alpha_{3} \beta_{2} \gamma_{2}, \alpha_{4} \beta_{2} \gamma_{2}, \alpha_{5} \beta_{2} \gamma_{2}$ and $\alpha_{6} \beta_{2} \gamma_{2}$. ${ }^{140}$

(4) Chiral 3-substituted $\beta$-carbolines. Examination of the binding data for the enantiomeric pair of $\beta$-carboline sec-butyl esters 23 and 24 (Table 3) indicated that the (R)-enantiomer 24 bound tighter to the receptor subtypes than the $(\mathrm{S})$ isomer 23. Although both enantiomers exhibited approximately a 4fold selectivity for the $\alpha_{1} \beta_{3} \gamma_{2}$ subtype, the (R) isomer remained more potent in vitro at all 5 sites. Because the receptor subtype selectivity remained about the same for the $(\mathrm{R})$ and $(\mathrm{S})$ isomers, this indicated the stereoenvironment in lipophilic pocket $\mathrm{L}_{1}$ was highly conserved across the entire series of 
BzR subtypes in agreement with earlier work on the binding affinities of the enantiomers of the framework-constrained 4,5-substituted pyrroloimidazobenzodiazepines. ${ }^{145}$ It was possible that lipophilc pocket $\mathrm{L}_{1}$ was simply a large area in the pharmacophore/receptor model with only small steric differences between receptor subtypes. More work will be required to determine if this is the case. A similar result was observed in the case of $(\mathrm{R})$ and $(\mathrm{S})$ isomers of CMD-30. The (R)-enantiomer CMD-30 $\mathrm{R}(\mathbf{2 2})$ bound slightly tighter to the receptor subtype than the $(\mathrm{S})$ isomer $(\mathbf{2 1})$ with almost 70 fold more selectivity for the $\alpha_{1}$ subtype over the $\alpha_{5}$ isoform. In addition, previously it was reported that a hydrogen bond between the $N$ (9) $\mathrm{H}$ atom of a $\beta$-carboline and the secondary site $A_{2}$ in the receptor pharmacophore was required for potent inverse agonist activity in vivo..$^{80,81}$ Therefore, a series of ligands with the Boc protection at position-9 such as 34-36 were evaluated and were not $\alpha_{1}$ subtype selective ligands. In fact, they did not bind to BzR at all in agreement with previous work. ${ }^{132}$

Table 3. Affinities $\left(K_{i}=n M\right)$ of chiral 3-substituted $\beta$-carbolines at $\alpha_{x} \beta_{2} \gamma_{2}(x=1-3,5,6)$ receptor subtypes

\begin{tabular}{|c|c|c|c|c|c|c|}
\hline Ligands & $\alpha_{1}$ & $\alpha_{2}$ & $\alpha_{3}$ & $\alpha_{4}$ & $\alpha_{5}$ & $\alpha_{6}$ \\
\hline 21 & 90 & 931 & 172 & $>3000$ & 1847 & $>2000$ \\
\hline & 27.0 & 343.3 & 453 & $>3000$ & 1847 & $>2000$ \\
\hline 23 & 17 & 59 & 88 & NA & 1444 & $>3000$ \\
\hline 24 & 7.7 & 32.5 & 43 & NA & 69 & $>2000$ \\
\hline
\end{tabular}

The affinity of compounds at $\mathrm{GABA}_{\mathrm{A}} / \mathrm{BzR}$ recombinant subtypes was measured by competition for $\left[{ }^{3} \mathrm{H}\right]$ flunitrazepam 
binding to HEK cell membranes expressing human receptors of composition $\alpha_{1} \beta_{2} \gamma_{2}, \alpha_{2} \beta_{2} \gamma_{2}, \alpha_{3} \beta_{2} \gamma_{2}, \alpha_{4} \beta_{2} \gamma_{2}, \alpha_{5} \beta_{2} \gamma_{2}$ and $\alpha_{6} \beta_{2} \gamma_{2} .{ }^{140}$

Table 3. Affinities $\left(\mathrm{K}_{\mathrm{i}}=\mathrm{nM}\right)$ of Boc-protected 3-substituted $\beta$-carbolines at $\alpha_{x} \beta_{2} \gamma_{2}(x=1-3,5,6)$ receptor subtypes.

\begin{tabular}{|c|c|c|c|c|c|c|}
\hline Ligands & $\alpha_{1}$ & $\alpha_{2}$ & $\alpha_{3}$ & $\alpha_{4}$ & $\alpha_{5}$ & $\alpha_{6}$ \\
\hline 34 & 450 & 5000 & ND & ND & 5000 & 5000 \\
\hline \multirow{2}{*}{35} & ND & ND & ND & ND & 1847 & ND \\
\hline & & & & & & \\
\hline
\end{tabular}

(5) Efficacy of $\alpha_{1}$ Preferring Ligands in oocytes at GABA $A_{A}$ Receptor Channels. The physiological efficacy of $\beta \mathrm{CCt}$, as compared to other $\mathrm{Bz}$ antagonists, was investigated across all diazepam sensitive (DS) receptor subunits at recombinant $\alpha_{1}, \alpha_{2}, \alpha_{3}$, and $\alpha_{5}$ receptor subunits in the Xenopus oocytes assay and is depicted in Figure 2 by Harvey et al. ${ }^{2,65}$ In comparison to other BzR antagonists such as flumazenil and ZK 93426, as mentioned, $\beta C C t$ exhibited either a neutral or lowefficacy agonist response at GABA $\alpha_{1}(96 \pm 7 \%), \alpha_{2}(99 \pm 10 \%), \alpha_{3}(108 \pm 6 \%)$, and $\alpha_{4}(107 \pm 5 \%)$ receptors. However, a low-efficacy partial inverse agonist response was observed at the $\alpha_{5}$ receptor $(88 \pm 7 \%$ of the GABA response). Flumazenil exhibited an efficacy profile that was qualitatively similar to $\beta C C t$ at the $\alpha_{1}(99 \pm 5 \%), \alpha_{3}(118 \pm 7 \%)$, and $\alpha_{5}(96 \pm 6 \%)$ subtypes. At the $\alpha_{2}$ receptor, flumazenil produced a low-efficacy agonist response $(115 \pm 4 \%)$, while $\beta C C t$ was GABA neutral $(99 \pm 10 \%)$. Flumazenil also produced a qualitatively similar response to $\beta \mathrm{CCt}$ at the $\alpha_{4}$ receptor, albeit the 
magnitude of GABA potentiation by flumazenil far exceeded that of $\beta C C t(132 \pm 6$ vs. $108 \pm 6 \%$, respectively). However, it is important to note, with regard to $\alpha_{4} / \alpha_{6} \beta_{2} \gamma_{2}$ subtypes, the agonist effect was observed at $10 \mu \mathrm{M}$, far above that required for agonist efficacy at the DS subtypes. In contrast, ZK 93426 produced a clear agonist profile, potentiating GABAergic activity by $137 \pm 8-148 \pm 11 \%$ across the $\alpha_{1}-\alpha_{4}$ subtypes, but was GABA neutral at the $\alpha_{5}$ receptor $(96 \pm 6 \%)$. These findings suggested that $\beta C C t$ had no appreciable intrinsic efficacy. The rationale for referring to this agent as a "mixed agonistantagonist" was based on the fact that, despite the ability to potentiate GABA at certain receptor subtypes, it was "GABA neutral" at select doses. In addition, at select doses, $\beta \mathrm{CCt}$ and 3 -P $\beta \mathrm{C}$ were capable of competitive antagonism of classical benzodiazepine agonists, ${ }^{88,90,106}$ therefore, the development of subtype-selective antagonists for $\mathrm{GABA}_{\mathrm{A}}$ receptors, such as $\beta \mathrm{CCt}$, which targeted the $\mathrm{GABA}_{\mathrm{A}} \alpha_{1}$ receptor as a weak agonist-like antagonist, ${ }^{76}$ can facilitate efforts to understand the antialcohol action of $\beta$-carbolines in nonhuman and human primates alike.

In the NIMH supported PDSP screen ( Roth, Evans, et al., UNC), neither $\beta C C T$, 3PBC, nor WYS8 exhibited significant interactions at other receptors (see http://pdsp.med.unc.edu for details).

\section{Conclusion}

Ethanol allosterically modulates the GABA receptor complex to open the chloride channel and hyperpolarize cells. At the pharmacological level, the effects of ethanol can be antagonized with GABA antagonists. $^{119}$ Unfortunately, the paucity of high affinity subtype selective ligands capable of discriminating among the various $\mathrm{GABA}_{\mathrm{A}}$ receptor subtypes has, thus far, precluded study of the precise role $\mathrm{GABA}_{\mathrm{A}}$ subunits play in mediating EtOH-maintained responding.

A series of $\beta$-carboline ligands described here has exhibited some selectivity at the $\alpha_{1}$ receptor subtype which included $\beta$-carboline-3-carboxylate- $t$-butyl ester $(\beta C C t, 1)$ and 3-propoxy- $\beta$-carboline hydrochloride (3-PBC, 2). These ligands displayed a 20-fold and 10-fold selectivity, respectively, for the $\alpha_{1}$ subtype over the $\alpha_{2}$ and $\alpha_{3}$ receptors, as well as over 150 -fold selectivity for the $\alpha_{1}$ site over the $\alpha_{5}$ 
subtype. ${ }^{2,3} \beta C C t(\mathbf{1})$ was more selective at the $\alpha_{1}$ subtype in vitro than the classical $\alpha_{1}$ selective agonists zolpidem (3) and CL $218872(4) .^{88,103,104} \beta C C t$ and 3-PBC are capable of competitive antagonism of classical benzodiazepine agonists, ${ }^{88,90,106}$ therefore, the development of subtype-selective antagonists for $\mathrm{GABA}_{\mathrm{A}}$ receptors which targets the $\mathrm{GABA}_{\mathrm{A}} \alpha_{1}$ receptor as a weak agonist-like antagonist, ${ }^{76}$ can facilitate antialcohol efforts to understand the action of $\beta$-carbolines in nonhuman and human primates alike. Compared with Naltrexone, the reductions in alcohol responding were more selective and longer in duration. ${ }^{117}$ The goal of this study was to identify novel $\alpha_{1}$ GABA $_{\mathrm{A}}$ subtype-preferring ligands that may serve as prototypes for further evaluation of clinical efficacy. These types of compounds may provide treatments for excessive alcohol drinking and the negative affective states associated with abstinence. Ligands that enhance GABAergic tone may be effective and safe treatments for both excessive alcohol drinking and the negative affective states associated with abstinence. This may represent novel, new pharmacotherapies to treat alcoholism.

Studies of the structure-activity relationships confirmed that occupation of region $\mathrm{L}_{\mathrm{Di}}$ of the receptor pharmacophore model did enhance $\alpha_{1}$ selectivity in comparison to the affinity of the nonselective ligands or the $\alpha_{5}$ selective ligands. Full occupation of the $\mathrm{L}_{\mathrm{Di}}$ lipophilic region by $\beta$ carbolines may account for the potency/selectivity of this class of ligands at the $\alpha_{1}$ subunit. Based on the SAR, the most potent $\alpha_{1}$ selective ligand was 6-substituted acetylenyl $\beta C C t$ (WYS8, 2). It was suggested the attenuation of EtOH-motivated responding effected by WYS8 (2) will be mediated via the $\alpha_{1}$ selective antagonism of the $\mathrm{GABA}_{\mathrm{A}} / \mathrm{BzR}$ receptor. ${ }^{2}$ In regard to ester functions at $\mathrm{C}(3)$, although both (R) and (S) enantiomers exhibited approximately a 4-fold selectivity for the $\alpha_{1} \beta_{3} \gamma_{2}$ subtype, the (R) isomer remained more potent in vitro at all $5 \mathrm{BzR}$ sites. Two factors affected high affinity binding at BzR with respect to $\beta$-carbolines, one of which was the lipophilicity of the substituent which interacted at $\mathrm{L}_{1}$. The second factor was the ability of the substituent at position-3 to release electron density to the pyridine ring.

The most selective ligand for $\alpha_{1}$ subtypes, to date, to these authors' knowledge was WYS8 (7). 
This 6-substituted acetylenyl $\beta C C t$ (7) was 214 fold more selective for $\alpha_{1}$ isoforms over $\alpha_{5}$ isoforms. WYS 8 can clearly be differentiated from nonselective BDZs by its selective binding affinity at the $\alpha_{1}$ receptor subunit and reduced capacity to potentiate GABA in Xenopus oocytes.

Innate elevations of the $\alpha_{1}$ and $\alpha_{2}$ subunits of the HAD rat may contribute to the capacity of novel $\beta$-carboline ligands to function as both anxiolytic agents and alcohol antagonists in this genetic rat line. ${ }^{117}$ These differences may explain the capacity of these novel $\beta$-carboline ligands to block alcohol drinking and exhibit anxiolytic actions in the P and HAD alcoholic rats. WYS8 may be a suitable ligand to evaluate as a preclinical agent to reduce alcohol dependence. Its reduced efficacy at the $\alpha_{1-2}$ subunits in potentiating GABA may render it a safe BDZ receptor ligand devoid of synergistic interactions with alcohol.

\section{Experimental Section:}

Melting points were taken on a Thomas-Hoover melting point apparatus or an Electrothermal Model IA8100 digital melting point apparatus and are reported uncorrected. Proton NMR spectra were recorded on a Bruker 250- or 300-MHz multiple-probe instrument. Infrared spectra were recorded on a Nicolet DX FTIR BX V5.07 spectrometer or a Mattson Polaris IR-10400 instrument. Low-resolution mass spectral data (EI/CI) were obtained on a Hewlett-Packard 5985B GC-mass spectrometer, while high resolution mass spectral data were taken on a VG autospectrometer (Double Focusing High Resolution GC/Mass Spectrometer, UK). Microanalyses were performed on a CE Elantech EA1110 elemental analyzer. Analytical TLC plates employed were E. Merck Brinkman UV active silica gel (Kieselgel 60 F254) on plastic, and silica gel 60b for flash chromatography was purchased from E. M. Laboratories. All chemicals were purchased from Aldrich Chemical Co. unless otherwise stated. All solvents were dried according to the published procedures.

1,2,3,4-Tetrahydro-9H-pyrido [3,4-b] indole-3-carboxylic acid (11). D, L-tryptophan (1000 g, $4.9 \mathrm{~mol})$ was added to a solution of aq sodium hydroxide $(12 \mathrm{~L}, 0.4 \mathrm{~N})$ after which the mixture was 
stirred until it dissolved. Formaldehyde $(560 \mathrm{~mL}$ of a $37 \%$ aq solution, $6.9 \mathrm{~mol})$ was added and the solution was allowed to stir for three days at $37^{\circ} \mathrm{C}$. Glacial acetic acid $(400 \mathrm{~mL})$ was added which resulted in the precipitation of a solid as a fine suspension. The mixture was allowed to stir for two days, after which additional solid formed. The solid was filtered from the medium, washed with water (4 x $1000 \mathrm{~mL}$ ), and dried to give 37 (953g, 90.0\%). 11: $\mathrm{mp} 295{ }^{\circ} \mathrm{C}\left(\text { lit } \mathrm{mp} 293{ }^{\circ} \mathrm{C}\right)^{146}$ (lit mp $\left.286{ }^{\circ} \mathrm{C}\right){ }^{147}$ (IR (KBr) 3600-2300, $1630 \mathrm{~cm}^{-1} ; \mathrm{MS}\left(\mathrm{CI}, \mathrm{CH}_{4}\right), \mathrm{m} / \mathrm{z}$ (relative intensity) $217\left(\mathrm{M}^{+}+1,50\right), 216(62)$, 169(59), 144(100). This material was employed directly in the next step.

Ethyl 1,2,3,4-tetrahydro-9H-pyrido[3,4-b]indole-3-carboxylate (12). The 1,2,3,4-tetra-hydro9H-pyrido[3,4-b]indole-3-carboxylic acid 11 (500 g, 2.3 mol) was dissolved in anhydrous ethanol (9 L) in a 12L (3 neck) flask, and conc sulfuric acid $(98 \%, 245 \mathrm{~mL}, 4.6 \mathrm{~mol})$ was carefully added to the solution until most of the solid dissolved. The reaction mixture was heated to reflux under nitrogen until the starting material was no longer detected by TLC on silica gel (48 h), and the solution became homogeneous. The reaction solution was cooled and the solvent removed under reduced pressure. The residue was dissolved in $\mathrm{H}_{2} \mathrm{O}(6.4 \mathrm{~L})$ and the $\mathrm{pH}$ of the solution adjusted to 8 with cold aq $\mathrm{NH}_{4} \mathrm{OH}$ (conc.) after which a precipitate formed. This mixture was then extracted with $\mathrm{CHCl}_{3}(6 \times 2.5 \mathrm{~L})$. The combined organic layers were dried $\left(\mathrm{Na}_{2} \mathrm{SO}_{4}\right)$ and the solvent was removed under reduced pressure to yield a light tan solid which was dried in a vacuum oven at $100{ }^{\circ} \mathrm{C}$ to provide $12(465 \mathrm{~g}, 83 \%) .11: \mathrm{mp}$ $150{ }^{\circ} \mathrm{C}$ (lit. mp 149-150 $\left.{ }^{\circ} \mathrm{C}\right) ;{ }^{98,148}{ }^{1} \mathrm{H}\left(300 \mathrm{MHz}, \mathrm{CDCl}_{3}\right) \delta 1.33(\mathrm{t}, J=7.32 \mathrm{~Hz}, 3 \mathrm{H}), 2.45(\mathrm{~s}(\mathrm{br}), 1 \mathrm{H})$, $2.88(\mathrm{dd}, J=9.70 \mathrm{~Hz}, J=15.37 \mathrm{~Hz}, 1 \mathrm{H}), 3.13(\mathrm{dd}, J=4.76 \mathrm{~Hz}, J=15.5 \mathrm{~Hz}, 1 \mathrm{H}), 3.77(\mathrm{dd}, J=4.76$ $\mathrm{Hz}, J=9.70 \mathrm{~Hz}, 1 \mathrm{H}), 4.07(\mathrm{~s}(\mathrm{br}), 2 \mathrm{H}), 4.26(\mathrm{q}, J=7.14 \mathrm{~Hz}, 2 \mathrm{H}), 7.18-7.08(\mathrm{~m}, 2 \mathrm{H}), 7.29(\mathrm{~d}, J=7.87$ Hz, 1H), 7.48 (d, J=7.68 Hz, 1H), 8.17 (s(br), 1H); MS (CI CH 4$)$ m/e 144 (97.3), 245 (M+1, 87), 244 (100), 183 (6), 171 (33), 144 (83). This material was employed directly in the next step.

Ethyl 9H-pyrido[3,4-b]indole-3-carboxylate (8). Into a round bottom flask (12 L) equipped with a reflux condenser and an overhead stir was added 1,2,3,4-tetrahydro- $\beta$-carboline-3-carboxylic acid ethyl ester $39(200 \mathrm{~g}, 0.86 \mathrm{~mol})$ and dry benzene $(8 \mathrm{~L})$. The solution was allowed to heat to reflux at which time activated $\mathrm{MnO}_{2}(200 \mathrm{~g})$ was added to the flask. Additional quantities of activated $\mathrm{MnO}_{2}$ 
were added until analysis by TLC (silica gel/ethyl acetate) indicated the absence of starting material. The hot solution was filtered through a bed of celite to remove the $\mathrm{MnO}_{2}$ and the filter cake was washed with hot benzene. The benzene layers were allowed to cool. A precipitate formed and was collected by vacuum filtration, which provided $(100-120 \mathrm{~g}, 50 \%-60 \%)$ of pure $\beta$-carboline-3-carboxylic acid ethyl ester 8 ( $\beta C C E)$. The benzene which remained in the filtrate was removed under reduced pressure to provide $25-35 \mathrm{~g}$ of additional $\beta \mathrm{CCE}$, but as crude material. The crude material could be purified by recrystalization from ethanol. 8: $\mathrm{mp} 225-227{ }^{\circ} \mathrm{C}$ (lit. 224-229 $\left.{ }^{\circ} \mathrm{C}\right) ;{ }^{148,}{ }^{149}{ }^{1} \mathrm{H}(300 \mathrm{MHz}$, DMSO-d 6 ) $\delta$ $1.36(\mathrm{t}, J=6.95 \mathrm{~Hz}, 3 \mathrm{H}), 4.37$ (q, $J=6.95 \mathrm{~Hz}, 2 \mathrm{H}), 7.37-7.24(\mathrm{~m}, 1 \mathrm{H}), 7.68-7.57$ (m, 2H), 8.38 (d, $J=$ $7.87 \mathrm{~Hz}, 1 \mathrm{H}), 8.90$ (s, 1H), 8.97 (s, 1H), 10.7 (br, 1H); MS (CI, CH $)_{4} \mathrm{~m} / \mathrm{e} 241\left(\mathrm{M}^{+}+1,47\right), 195(22)$, 168 (100), 140 (9). This material was employed directly in the next step.

$\beta$-Carboline-3-carboxylic acid (9). $\beta$-Carboline-3-carboxylic acid ethyl ester 8 (30.0 g, 0.126 mol) was suspended in aq $\mathrm{NaOH}(10 \%, 1.5 \mathrm{~L})$ and heated to reflux until all the material had gone into solution $(1 \mathrm{~h})$. The heating was continued for an additional $3 \mathrm{~h}$. The reaction mixture was cooled to $\mathrm{rt}$ and acidified by addition of ice cold aq conc $\mathrm{HCl}$ to $\mathrm{pH} 4$. The precipitate which resulted was stirred overnight. The solid was collected by vacuum filtration and washed with $\mathrm{H}_{2} \mathrm{O}(2 \times 150 \mathrm{~mL})$. The product was dried at $80{ }^{\circ} \mathrm{C}$ under vacuum for $24 \mathrm{~h}$ to provide $9(26.1 \mathrm{~g}, 99 \%) .9: \mathrm{mp} 220-221{ }^{\circ} \mathrm{C}$ (lit. $\mathrm{mp}$ $\left.220{ }^{\circ} \mathrm{C}\right) ;{ }^{68} \mathrm{IR}(\mathrm{KBr}) 3260,2970,1710 \mathrm{~cm}^{-1} ;{ }^{1} \mathrm{H} \mathrm{NMR}\left(\mathrm{CDCl}_{3}\right) \delta 7.31(\mathrm{t}, J=7.32 \mathrm{~Hz}, 1 \mathrm{H}), 7.69-7.57(\mathrm{~m}$, 2H), $8.38(\mathrm{~d}, J=7.87 \mathrm{~Hz}, 1 \mathrm{H}), 8.90(\mathrm{~s}, 1 \mathrm{H}), 8.96(\mathrm{~s}, 1 \mathrm{H}), 12.10(\mathrm{~s}, 1 \mathrm{H}, \mathrm{NH}) .(\mathrm{s}, 1 \mathrm{H}) ; \mathrm{MS}\left(\mathrm{CI}_{1} \mathrm{CH}_{4}\right), \mathrm{m} / \mathrm{e}$ $\left(\mathrm{M}^{+}+1\right.$, 269). Anal. Calcd. for $\mathrm{C}_{16} \mathrm{H}_{16} \mathrm{~N}_{2} \mathrm{O}_{2}\left(0.55 \mathrm{H}_{2} \mathrm{O}\right)$ : C, 69.07; H, 6.19; N, 10.07. Found: $\mathrm{C}, 68.81$; H, 5.77; N, 10.00 .

$\beta$-Carboline-3-carboxylic acid t-butyl ester (1). To a solution of carbonyl diimidazole (28.2 g, $0.177 \mathrm{~mol})$ in anhydrous DMF (1.2 L) was added dry $\beta$-carboline-3-carboxylic acid 9 (25 g, $0.118 \mathrm{~mol})$ under argon. The reaction mixture was initially a pale yellow-colored suspension, but after stirring for $30 \mathrm{~min}$, a purple or red-colored solution resulted. The reaction mixture was stirred for an additional $2 \mathrm{~h}$ at rt and carbon dioxide was released during the reaction. Analysis by TLC (silica gel) indicated the 
absence of starting material on the baseline. To this reaction mixture was added dry DBU (18 g, 0.118 mol) and dry freshly distilled t-butyl alcohol $(437 \mathrm{~g} / 560 \mathrm{~mL}, 50 \mathrm{eq})$. The mixture was heated at $85^{\circ} \mathrm{C}$ for 18h until analysis by TLC indicated the disappearance of the imidazole intermediate. The solvent was then removed under reduced pressure. The residue was partitioned between $\mathrm{CH}_{2} \mathrm{Cl}_{2}(1.2 \mathrm{~L})$ and $\mathrm{H}_{2} \mathrm{O}$ (800 mL). The organic layer was separated and the $\mathrm{H}_{2} \mathrm{O}$ layer was extracted with $\mathrm{CH}_{2} \mathrm{Cl}_{2}(2 \times 500 \mathrm{~mL})$. The combined organic layer was washed with an aq solution of $10 \% \mathrm{~K}_{2} \mathrm{CO}_{3}$, water, brine and dried $\left(\mathrm{Na}_{2} \mathrm{SO}_{4}\right)$. The solvent was removed under reduced pressure and the residue was purified by flash chromatography (silica gel, EtOAc/hexane $=1: 1)$ to provide $\beta \mathrm{CCt}(20 \mathrm{~g}, 65 \%)$ as a white solid. $\beta \mathrm{CCt}$ can be recrystallized from EtOAc to provide white crystals 1: mp $301-303^{\circ} \mathrm{C}$ (lit. mp 298-300), ${ }^{82} \mathrm{IR}$ (KBr) 3500-3400, 3200-3000, 1610, 1560, 1370, $1340 \mathrm{~cm}^{-1} ;{ }^{1} \mathrm{H}(300 \mathrm{MHz}$, DMSO-d 6$) \delta 1.36(\mathrm{t}, 3 \mathrm{H}$, $\mathrm{J}=6.95 \mathrm{~Hz}), 4.37(\mathrm{q}, 2 \mathrm{H}, \mathrm{J}=6.95 \mathrm{~Hz}), 7.37-7.24(\mathrm{~m}, 1 \mathrm{H}), 7.68-7.57(\mathrm{~m}, 2 \mathrm{H}), 8.38(\mathrm{~d}, 1 \mathrm{H}, \mathrm{J}=7.87 \mathrm{~Hz}), 8.90$ $(\mathrm{s}, 1 \mathrm{H}), 8.97(\mathrm{~s}, 1 \mathrm{H}), 10.7((\mathrm{br}), 1 \mathrm{H})$; The spectral data for 1 were identical to those reported in the literature. $^{92}$

2,2,2-Trifluoroethyl $\beta$-carboline-3-carboxylate 15 was prepared from $\beta$-carboline-3-carboxylic acid $\mathbf{9}$ and 2,2,2-trifluoroethyl alcohol following the procedure employed for the preparation of $\mathbf{1}$. 15: $\mathrm{mp} 264-266{ }^{\circ} \mathrm{C}$; IR (NaCl) 3275, $1735 \mathrm{~cm}^{-1} ;{ }^{1} \mathrm{H}$ NMR (300 MHz, $\left.\mathrm{CDCl}_{3}\right) 4.87(\mathrm{~m}, 2 \mathrm{H}), 7.42(\mathrm{~m}$, 1H), $7.65(\mathrm{~m}, 2 \mathrm{H}), 8.24(\mathrm{~d}, J=7.9 \mathrm{~Hz}, 1 \mathrm{H}), 8.93(\mathrm{~s}, 1 \mathrm{H}), 9.09(\mathrm{~s}, 1 \mathrm{H}), 9.10(\mathrm{~s}, \mathrm{br}, 1 \mathrm{H}) ; \delta 60.4,60.8$, $112.8,118.9,120.7,121.2,122.7,127.8,129.2,134.5,135.2,138.1,141.3,164.5 ; \mathrm{MS}$ (EI) m/e (relative intensity) 294(M+, 30), 195(7), 168(100), 167(42). Anal. Calcd. for $\mathrm{C}_{14} \mathrm{H}_{9} \mathrm{~F}_{3} \mathrm{~N}_{2} \mathrm{O}_{2}$ : C, 57.15; H, 3.08; N, 9.52. Found: C, 57.22; H, 3.14; N, 9.23.

9H- $\beta$-Carboline-3-carboxylic acid 2,2,2-trifluoro-1-trifluoromethyl-ethyl ester 16 was prepared following the procedure employed for the preparation of 1. 16: ${ }^{1} \mathrm{H}$ NMR (300 MHz, DMSO$\left.\mathrm{d}_{6}\right) \delta$ 7.05-7.21 (m, 1H), 7.33-7.44 (t, 1H), 7.61-7.72 (m, 2H), $8.48(\mathrm{~d}, J=7.89 \mathrm{~Hz}, 1 \mathrm{H}), 9.09(\mathrm{~s}, 2 \mathrm{H})$, $12.31(\mathrm{~s}, 1 \mathrm{H}) ;{ }^{13} \mathrm{C}$ NMR $\left(75.5 \mathrm{MHz}\right.$, DMSO-d $\left.{ }_{6}\right) \delta 65.9,66.8,112.9,120.1,120.9,122.8,127.8,129.4$, 
133.3, 134.9, 138.4, 141.3, 162.9. This material was pure by TLC (silica gel).

9H- $\beta$-Carboline-3-carboxylic acid 2,2,2-trichloro-ethyl ester 17 was prepared following the procedure employed for the preparation of 1. 17: ${ }^{1} \mathrm{H}$ NMR $\left(300 \mathrm{MHz}, \mathrm{CDCl}_{3}\right) \delta 5.17(\mathrm{~s}, 2 \mathrm{H}), 7.38-7.44$ (m, 1H), 7.63-7.74 (m, 2H), $8.27(\mathrm{~d}, J=7.95 \mathrm{~Hz}, 1 \mathrm{H}), 8.95(\mathrm{~s}, 1 \mathrm{H}), 9.21(\mathrm{~s}, 1 \mathrm{H}), 9.66(\mathrm{~s}, 1 \mathrm{H})$. This material was pure by TLC (silica gel).

9H- $\beta$-Carboline-3-carboxylic acid 2,2,2-trifluoro-1-methyl-ethyl ester 18 was prepared following the procedure employed for the preparation of 1. 18: m.p. $247-249{ }^{\circ} \mathrm{C}$; IR (NaCl) 2359,1729 , $1345,1251,1092,729,450 \mathrm{~cm}^{-1} ;{ }^{1} \mathrm{H}$ NMR $\left(300 \mathrm{MHz}, \mathrm{CDCl}_{3}\right) \delta 1.82(\mathrm{~d}, J=6.1 \mathrm{~Hz}, 3 \mathrm{H}), 5.96(\mathrm{q}, 1 \mathrm{H})$, $7.42(\mathrm{t}, 1 \mathrm{H}), 7.67(\mathrm{~m}, 2 \mathrm{H}), 8.26(\mathrm{~d}, J=7.6 \mathrm{~Hz}, 1 \mathrm{H}), 8.8(\mathrm{~s}, 1 \mathrm{H}), 8.9(\mathrm{~s}, 1 \mathrm{H}), 9.5(\mathrm{br}, 1 \mathrm{H}) ;{ }^{13} \mathrm{C}$ NMR $(75.5$ $\left.\mathrm{MHz}, \mathrm{CDCl}_{3}\right) \delta 16.5,79.1,112.3,118.5,121.2,121.5,121.9,128.8,129.2,133.9,137.4$. This material was pure by TLC ( silica gel).

(S)-1,1,1-Trifluoroisopropyl $\beta$-carboline-3-carboxylate (21). To a solution of carbonyl diimidazole $(0.168 \mathrm{~g}, 1.03 \mathrm{mmol})$ in anhydrous DMF $(5 \mathrm{~mL}), \beta$-carboline-3-carboxylic acid $9(0.10 \mathrm{~g}$, $0.47 \mathrm{mmol}$ ) was added. The reaction mixture which resulted was stirred for $2 \mathrm{~h}$ at $\mathrm{rt}$ until analysis by TLC (silica gel) indicated the absence of starting material on the baseline. The solution which resulted was then cooled to $-6^{\circ} \mathrm{C}$ and this was followed by addition of (S)-1,1,1-trifluoropropan-2-ol (2.3 eq) which was contaminated with some EtOH. The dry DBU (100 mg, $0.68 \mathrm{mmol})$ in dry DMF $(0.5 \mathrm{~mL})$ was slowly syringed into the reaction mixture at $-6{ }^{\circ} \mathrm{C}$. The mixture was stirred at $0{ }^{\circ} \mathrm{C}$ for $8 \mathrm{~h}$ until analysis by TLC (silica gel) indicated the diaspperance of the imidazole intermediate. The reaction mixture was then poured into ice water $(30 \mathrm{~mL})$ and extracted with $\mathrm{CH}_{2} \mathrm{Cl}_{2}(3 \times 40 \mathrm{~mL})$. The combined organic layers were washed with $\mathrm{H}_{2} \mathrm{O}(5 \times 40 \mathrm{~mL})$, brine and dried $\left(\mathrm{Na}_{2} \mathrm{SO}_{4}\right)$. The solvent was removed under reduced pressure and the residue was purified by flash chromatography (silica gel, EtOAc/hexanes $=2: 1)$ to provide $21(0.113 \mathrm{~g}, 78 \%)$ as a white solid. 21: $\mathrm{mp} 239-241{ }^{\circ} \mathrm{C} ;[\alpha]_{\mathrm{D}}^{27}=-9.62^{\circ}$ (c = 0.81, in $\left.\mathrm{CHCl}_{3}\right) ; \mathrm{IR}(\mathrm{NaCl}) 3266,1725,1502 \mathrm{~cm}^{-1} ;{ }^{1} \mathrm{H} \mathrm{NMR}\left(300 \mathrm{MHz}, \mathrm{CDCl}_{3}\right) \delta 1.63(\mathrm{~d}, J=6.6$ 
$\mathrm{Hz}, 3 \mathrm{H}), 5.75(\mathrm{~m}, 1 \mathrm{H}), 7.40(\mathrm{t}, J=7.5 \mathrm{~Hz}, 1 \mathrm{H}), 7.64(\mathrm{t}, J=7.6 \mathrm{~Hz}, 1 \mathrm{H}), 7.72(\mathrm{~d}, J=8.1 \mathrm{~Hz}, 1 \mathrm{H}), 8.25$

(d, $J=7.9 \mathrm{~Hz}, 1 \mathrm{H}), 8.91(\mathrm{~s}, 1 \mathrm{H}), 9.18(\mathrm{~s}, 1 \mathrm{H}), 10.04$ (s, br, 1H); MS (EI) m/e (relative intensity) 308

$\left(\mathrm{M}^{+}, 17\right), 168$ (100), 140 (21). Exact mass calcd. for $\mathrm{C}_{15} \mathrm{H}_{11} \mathrm{~F}_{3} \mathrm{~N}_{2} \mathrm{O}_{2}: 308.0773$. Found: 308.0773. Anal.

Calcd. for $\mathrm{C}_{15} \mathrm{H}_{11} \mathrm{~F}_{3} \mathrm{~N}_{2} \mathrm{O}_{2}$ : C, 58.45; H, 3.60; N, 9.09. Found: C, 58.15; H, 3.63; N, 8.88.

(S)-1,1,1-Trifluorobutan-2-ol was prepared following the literature procedure. ${ }^{124}$ To an oven-dried, 25 $\mathrm{mL}$ round-bottom flask was transferred (-)-DIP-Chloride (10.68 g, $33 \mathrm{mmol})$ in a glove box. Then 1,1,1trifluorobutan-2-one (4.03 g, $32 \mathrm{mmol})$ was added at $\mathrm{rt}$ under argon. The reaction mixture was stirred at rt for $10 \mathrm{~h}$. Ethyl ether was added and the reaction solution was cooled to $0{ }^{\circ} \mathrm{C}$ followed by addition of acetaldehyde (1.6 g, $1.1 \mathrm{eq})$. The reaction mixture was allowed to warm to rt and stirring was continued for $24 \mathrm{~h}$ while the second equivalent of $\alpha$-pinene was liberated. An aq solution of sodium hydroxide $(2.5 \mathrm{M}, 30 \mathrm{~mL})$ was added and the solution which resulted was extracted with ether $(3 \times 30 \mathrm{~mL})$. The ether layer was dried $\left(\mathrm{Na}_{2} \mathrm{SO}_{4}\right)$ and fractionally distilled through a Pyrex distilling column packed with glass beads. The desired alcohol was collected along with EtOH (20\%). (S)-1,1,1-Trifluorobutan-2-ol: ${ }^{1} \mathrm{H} \mathrm{NMR}\left(300 \mathrm{MHz}, \mathrm{CDCl}_{3}\right)$ 1.04(dt, 3H, J= $0.6 \mathrm{~Hz}$ and $\left.\mathrm{J}=7.4 \mathrm{~Hz}\right), 1.58(\mathrm{~m}, 1 \mathrm{H}), 1.72(\mathrm{~m}, 1 \mathrm{H}), 3.82(\mathrm{~m}$, 1H). This material was used in a later step without further purification.

(R)-1,1,1-Trifluoroisopropyl $\beta$-carboline-3-carboxylate 22 was prepared from the acid $\mathbf{9}$ and (R)-1,1,1-trifluoropropan-2-ol following the procedure employed for preparation of (S)-1,1,1-trifluoropropan-2-ol. 30: $\mathrm{mp} 239-241{ }^{\circ} \mathrm{C} ;[\alpha]_{\mathrm{D}}^{27}=8.73^{\circ}\left(\mathrm{c}=0.88\right.$, in $\left.\mathrm{CHCl}_{3}\right)$; The spectral data for 22 were identical to those for 21; however, the optical rotation was in the opposite direction.

(S)- $\beta$-Carboline-3-carboxylic acid sec-butyl ester (23). To a solution of carbonyl diimidazole (1.53 g, $9.4 \mathrm{mmol})$ in anhydrous DMF $(50 \mathrm{~mL})$ was added $\beta$-carboline-3-carboxylic acid 9 (1.0 g, 4.7 $\mathrm{mmol})$. The reaction mixture was stirred for $2 \mathrm{~h}$ at $\mathrm{rt}$ and carbon dioxide was released during the reaction. Analysis by TLC (silica gel) indicated the absence of starting material on the baseline. To this 
reaction mixture was added dry DBU (0.72 g, $4.7 \mathrm{mmol})$ and dry (S)-butyl alcohol (1.13 g, $15.2 \mathrm{mmol})$. The mixture which resulted was heated at $55^{\circ} \mathrm{C}$ for $8 \mathrm{~h}$ until analysis by TLC (silica gel) indicated the disappearance of the imidazole intermediate. The solvent was then removed under reduced pressure. The residue was partitioned between $\mathrm{CH}_{2} \mathrm{Cl}_{2}(100 \mathrm{~mL})$ and $\mathrm{H}_{2} \mathrm{O}(100 \mathrm{~mL})$. The organic layer was separated and the $\mathrm{H}_{2} \mathrm{O}$ layer was extracted with $\mathrm{CH}_{2} \mathrm{Cl}_{2}(2 \times 80 \mathrm{~mL})$. The combined organic layer was washed with $\mathrm{H}_{2} \mathrm{O}(3 \times 100 \mathrm{~mL})$, brine and dried $\left(\mathrm{Na}_{2} \mathrm{SO}_{4}\right)$. The solvent was removed under reduced pressure and the residue was purified by flash chromatography (silica gel, EtOAc/hexane $=2: 1$ ) to provide $23(0.96 \mathrm{~g}, 76 \%)$ as a white solid. 23: $\mathrm{mp} 212-213{ }^{\circ} \mathrm{C}$; $[\alpha]_{25}=35.6^{\circ}\left(\mathrm{CHCl}_{3}, \mathrm{c}=1.43\right)$; IR $(\mathrm{KBr})$ 3222, 1706, 1622, $1494 \mathrm{~cm}^{-1} ;{ }^{1} \mathrm{H}$ NMR (300 MHz, $\left.\mathrm{CDCl}_{3}\right) \delta 0.99(\mathrm{t}, J=7.5 \mathrm{~Hz}, 3 \mathrm{H}), 1.40(\mathrm{~d}, J=6.3$ $\mathrm{Hz}, 3 \mathrm{H}), 1.79(\mathrm{~m}, 2 \mathrm{H}), 5.27(\mathrm{~m}, 1 \mathrm{H}), 7.34(\mathrm{t}, J=7.9 \mathrm{~Hz}, 1 \mathrm{H}), 7.57(\mathrm{t}, J=7.8 \mathrm{~Hz}, 1 \mathrm{H}), 7.79(\mathrm{~d}, J=8.3$ $\mathrm{Hz}, 1 \mathrm{H}), 8.21(\mathrm{~d}, J=7.9 \mathrm{~Hz}, 1 \mathrm{H}), 11.47(\mathrm{~s}, \mathrm{br}, 1 \mathrm{H})$; MS (CI, CH4) m/e (relative intensity) 269( $\mathrm{M}^{+}+1$, 100), 241(15), 213(41), 195(14). Anal. Calcd. for $\mathrm{C}_{16} \mathrm{H}_{16} \mathrm{~N}_{2} \mathrm{O} 2$ : $\mathrm{C}, 71.62 ; \mathrm{H}, 6.01 ; \mathrm{N}, 10.44$. Found: C, 71.33; H, 6.09; N, 10.26 .

(R)- $\beta$-Carboline-3-carboxylic acid sec-butyl ester $\mathbf{2 4}$ was prepared in 75\% yield following the procedure for preparation of 1. 24: $[\alpha]_{25}=-35.2^{\circ}\left(\mathrm{CHCl}_{3}, \mathrm{c}=1.25\right)$ The spectral data for 22 were identical to those for $\mathbf{2 3}$.

6-Iodo-9H- $\boldsymbol{\beta}$-carboline-3-carboxylic acid t-butyl ester (5). Into a round bottom flask ( $250 \mathrm{~mL}$ ) was added $\mathrm{CF}_{3} \mathrm{CO}_{2} \mathrm{Ag}(1.03 \mathrm{~g}, 4.67 \mathrm{mmol}), \beta$-carboline-3-carboxylic acid t-butyl ester 9 (1.02 g, 3.83 mmol), and $\mathrm{CHCl}_{3}(100 \mathrm{~mL})$. This was followed by addition of iodine $(1.15 \mathrm{~g}, 4.66 \mathrm{mmol})$. The reaction mixture was allowed to stir at $\mathrm{rt}$ for $6 \mathrm{~h}$ after which another portion of $\mathrm{CF}_{3} \mathrm{CO}_{2} \mathrm{Ag}(500 \mathrm{mg}, 2.26$ mmol) was added and stirring continued for another $10 \mathrm{~h}$ at reflux. Analysis by TLC (silica gel) indicated that most of the $\beta \mathrm{CCt}$ had disappeared. The reaction mixture was filtered through a bed of celite to remove the solid salts and the filter cake was washed with EtOH $(3 \times 50 \mathrm{~mL})$. The solvent was removed under reduced pressure and the residue was purified by flash chromatography (silica gel, 
EtOAc/hexane $=4: 1)$ to provide $5(908 \mathrm{mg}, 65 \%)$ as a white solid. 5: $\mathrm{mp} 347-348{ }^{\circ} \mathrm{C}(\mathrm{dec}.) ; \mathrm{IR}(\mathrm{NaCl})$ $3223,1710,1485,1323,1245,1161,1104,1020 \mathrm{~cm}^{-1} ;{ }^{1} \mathrm{H}$ NMR $\left(300 \mathrm{MHz}, \mathrm{CDCl}_{3}\right) \delta 1.68$ (s, 9H), 7.63 $(\mathrm{d}, J=8.6 \mathrm{~Hz}, 1 \mathrm{H}), 7.85(\mathrm{dd}, J=1.5 \mathrm{~Hz}$ and $J=8.6 \mathrm{~Hz}, 1 \mathrm{H}), 8.53(\mathrm{~d}, J=1.4 \mathrm{~Hz}, 1 \mathrm{H}), 9.31(\mathrm{~s}, 1 \mathrm{H})$, $11.47(\mathrm{~s}, \mathrm{br}, 1 \mathrm{H}) ;{ }^{13} \mathrm{C} \mathrm{NMR}\left(75.7 \mathrm{MHz}, \mathrm{CDCl}_{3}\right) \delta 28.3,80.8,83.6,115.1,118.1,123.9,126.7,131.2$ 134.1, 136.8, 137.5, 138.7, 140.4, 164.9; $\mathrm{MS}(\mathrm{EI} 800) \mathrm{m} / \mathrm{e}$ (relative intensity) $395\left(\mathrm{M}^{+}+1,18\right), 367$ (20), 339 (100), 268 (33). Anal. Calcd. for $\mathrm{C}_{16} \mathrm{H}_{15} \mathrm{IN}_{2} \mathrm{O}_{2}: \mathrm{C}, 48.75 ; \mathrm{H}, 3.84 ; \mathrm{N}, 7.11$. Found: C, 49.01; H, $3.91 ; \mathrm{N}, 6.95$.

6-Trimethylsilanylethynyl-9H- $\beta$-carboline-3-carboxylic acid t-butyl ester (6). Into a round bottom flask $(50 \mathrm{~mL})$ which contained a solution of degassed $\mathrm{THF} / \mathrm{Et}_{3} \mathrm{~N}(10 \mathrm{~mL} / 2 \mathrm{~mL})$, was added 6iodo-9H- $\beta$-carboline-3-carboxylic acid t-butyl ester 5 (400 mg, $1.02 \mathrm{mmol}$ ), bis[triphenylphosphine] palladium dichloride (35 mg, $5 \mathrm{~mol} \%$ ) and copper(I) iodide (7 mg, $5 \mathrm{~mol} \%$ ) Note: Practically, on a small scale, $\mathrm{CuI}$ could be used up to $10-15$ mol\% because of its lower molecular weight compared to the palladium catalyst; on a bigger scale, both $\mathrm{Pd}\left(\mathrm{PPh}_{3}\right)_{2} \mathrm{Cl}_{2}$ and $\mathrm{CuI}$ can be used as low as $0.5-1 \mathrm{~mol} \%$. The reaction mixture was then degassed 2 times with an oil pump at $-78{ }^{\circ} \mathrm{C}$, and then the trimethylsilyl acetylene $(300 \mathrm{mg}, 3.06 \mathrm{mmol})$ was added into the mixture and it was degassed one more time at $-78^{\circ}$ C. The reaction mixture was gradually allowed to warm to $\mathrm{rt}$ and stirred at $\mathrm{rt}$ for an additional $0.5-1 \mathrm{~h}$ until all the starting material had disappeared (TLC analysis indicated that the original red spot changed color to purple, since both s.m. and product had very similar $\mathrm{R}_{\mathrm{f}}$ values). The solvent was removed under reduced pressure at this point and the residue was purified by flash chromatography (silica gel, EtOAc/hexane $=4: 1)$ to provide $6(340 \mathrm{mg}, 92 \%)$ as a white solid. ${ }^{1} \mathrm{H} \mathrm{NMR}\left(300 \mathrm{MHz}, \mathrm{CDCl}_{3}\right) \delta 1.71$ $(\mathrm{s}, 9 \mathrm{H}), 1.75(\mathrm{~s}, 9 \mathrm{H}), 7.67(\mathrm{~m}, 2 \mathrm{H}), 8.26(\mathrm{~d}, J=7.6 \mathrm{~Hz}, 1 \mathrm{H}), 8.8(\mathrm{~s}, 1 \mathrm{H}), 8.9(\mathrm{~s}, 1 \mathrm{H}), 9.5(\mathrm{br}, 1 \mathrm{H}) ;{ }^{13} \mathrm{C}$ $\operatorname{NMR}\left(75.5 \mathrm{MHz}, \mathrm{CDCl}_{3}\right) \delta 0.021,28.3,81.9,92.6,105.7,113.2,114.9,117.7,121.3,125.5,128.3$, 132.4, 133.8, 138.2, 138.4, 141.5, 165.4; EIMS 364(M+38), 293(12), 264(100), 249(48), 124(60). This material was employed directly in the next step. 
6-Ethynl-9H- $\beta$-carboline-3-carboxylic acid t-butyl ester (7)-WYS8. To a solution of 6trimethylsilanyl- $\beta$-carboline-3-carboxylic acid t-butyl ester 5 (850 mg, $2.32 \mathrm{mmol})$ in THF (10 mL) was added 1.2 eq of TBAF (2.8 mL of $1 \mathrm{M}$ TBAF/THF solution) at $0{ }^{\circ} \mathrm{C}$ and then the solution was allowed to warm to rt. After consumption of the starting material as indicated by TLC, $\mathrm{H}_{2} \mathrm{O}(10 \mathrm{~mL})$ was added and the mixture was extracted with $\mathrm{CH}_{2} \mathrm{Cl}_{2}(3 \times 20 \mathrm{~mL})$. The combined organic layer was concentrated under reduced pressure and the residue was chromatographed on a short silica gel column $($ EtOAc/hexane $=4: 1)$ to give $7(620 \mathrm{mg}, 92 \%)$ as a white solid. 7: ${ }^{1} \mathrm{H} \mathrm{NMR}\left(300 \mathrm{MHz}, \mathrm{CDCl}_{3}\right) \delta$ 1.75(s, 9H), 3.54(s, 1H), 7.62-7.85 (m, 2H), $8.41(\mathrm{~s}, 1 \mathrm{H}), 8.83(\mathrm{~s}, 1 \mathrm{H}), 9.33(\mathrm{~s}, 1 \mathrm{H}), 11.1(\mathrm{~s}, 1 \mathrm{H})$; EIMS $292\left(\mathrm{M}^{+}, 25\right), 236(12), 192(100), 164(30)$. This material was pure by TLC (silica gel) and used directly in the next step.

\section{6-Thiophen-2-yl-9H- $\beta$-carboline-3-carboxylic acid t-butyl ester (30a). Representative} Procedure for preparation of 6-subsitituted $\beta$-carbolines. A solution of 6-Iodo- $\beta$-carboline-3-carboxylic acid t-butyl ester $5(265 \mathrm{mg}, 0.67 \mathrm{mmol})$ in dry toluene $(15 \mathrm{~mL})$ was degassed under vacuum and

purged with dry $\mathrm{N}_{2}$ through the solution 3 times. The mixture was then heated to $140{ }^{\circ} \mathrm{C}$ under nitrogen after which tetrakis(triphenylphosphine) palladium (0) (77 $\mathrm{mg}, 0.067 \mathrm{mmol}, 10 \mathrm{~mol} \%)$ and 2(tributylstannyl) thiophene $(718 \mathrm{mg}, 2.01 \mathrm{mmol})$ were added in one portion. The mixture was heated to reflux under nitrogen. After $12 \mathrm{~h}$, the mixture was allowed to cool to $\mathrm{rt}$ and the precipitate which resulted was removed by vacuum filtration. The filtrate was concentrated under reduced pressure and the residue was treated with a saturated aq solution of $\mathrm{NaHCO}_{3}(30 \mathrm{~mL})$ and extracted with $\mathrm{CH}_{2} \mathrm{Cl}_{2}(3 \mathrm{x}$ $25 \mathrm{~mL})$. The combined extracts were washed with brine and dried $\left(\mathrm{Na}_{2} \mathrm{SO}_{4}\right)$. The solvent was removed under reduced pressure and the residue was purified by flash chromatography (silica gel, EtOAc/hexane $=5: 1)$ to provide a white solid 30a $(195 \mathrm{mg}, 83 \%)$. 30a: ${ }^{1} \mathrm{H} \mathrm{NMR}\left(300 \mathrm{MHz}, \mathrm{CDCl}_{3}\right) \delta 2.07(\mathrm{~s}, 9 \mathrm{H})$, $7.15(\mathrm{t}, 1 \mathrm{H}), 7.31(\mathrm{~d}, J=3 \mathrm{~Hz}, 1 \mathrm{H}), 7.40(\mathrm{~d}, J=3 \mathrm{~Hz}, 1 \mathrm{H}), 7.89(\mathrm{q}, 2 \mathrm{H}), 8.44(\mathrm{~s}, 1 \mathrm{H}), 8.89(\mathrm{~s}, 1 \mathrm{H}), 9.32$ $(\mathrm{s}, 1 \mathrm{H}), 11.2(\mathrm{~s}, 1 \mathrm{H})$. This material was pure by TLC (silica gel). 
6-Furan-2-yl-9H- $\beta$-carboline-3-carboxylic acid t-butyl ester 29a was prepared following the

procedure for preparation of 30a. 29a: ${ }^{1} \mathrm{H} \mathrm{NMR}\left(300 \mathrm{MHz}, \mathrm{CDCl}_{3}\right) \delta 1.63(\mathrm{~s}, 9 \mathrm{H}), 6.63(\mathrm{~m}, 1 \mathrm{H}), 6.97(\mathrm{~d}$, $J=6 \mathrm{~Hz}, 1 \mathrm{H}), 7.70(\mathrm{~d}, J=9 \mathrm{~Hz}, 1 \mathrm{H}), 7.77(\mathrm{~s}, 1 \mathrm{H}), 7.96(\mathrm{~d}, J=9 \mathrm{~Hz}, 1 \mathrm{H}), 8.73(\mathrm{~s}, 1 \mathrm{H}), 8.90(\mathrm{~s}, 1 \mathrm{H}), 8.96$ $(\mathrm{s}, 1 \mathrm{H}), 12.1(\mathrm{~s}, 1 \mathrm{H}) ;{ }^{13} \mathrm{C} \mathrm{NMR}\left(75.5 \mathrm{MHz}, \mathrm{CDCl}_{3}\right) \delta 14.3,22.4,28.4,31.3,78.9,80.7,102.3,104.6$, $104.9,106.3,112.4,113.2,117.4,117.8,121.7,123.5,125.1,127.1,127.8,133.6,134.1,138,140.6$ 142.6, 154.1, 165.0, 166.0. This material was pure by TLC (silica gel).

6-Furan-2-yl-9H- $\beta$-carboline-3-carboxylic acid 2,2,2-trifluoro-ethyl ester 29b was prepared following the procedure for preparation of 30a. 29b: ${ }^{1} \mathrm{H} \mathrm{NMR}\left(250 \mathrm{MHz}, \mathrm{CDCl}_{3}\right) \delta 4.82-4.92(\mathrm{~m}, 2 \mathrm{H})$, $6.54(\mathrm{~s}, 1 \mathrm{H}), 6.75(\mathrm{~s} 1 \mathrm{H}), 7.38(\mathrm{~s}, 1 \mathrm{H}), 7.65(\mathrm{~d}, J=10 \mathrm{~Hz}, 1 \mathrm{H}), 7.96(\mathrm{~d}, J=10 \mathrm{~Hz}, 1 \mathrm{H}), 8.5(\mathrm{~s}, 1 \mathrm{H}), 8.93$ $(\mathrm{s}, 1 \mathrm{H}), 9.13(\mathrm{~s}, 1 \mathrm{H}), 9.59(\mathrm{~s}, 1 \mathrm{H}) ;{ }^{13} \mathrm{C} \mathrm{NMR}\left(75.5 \mathrm{MHz}, \mathrm{CDCl}_{3}\right) \delta 60.9,105.3,112.5,112.8,113.3$ $117.6,119.2,122.3,123.8,125.3,127.9,134.7,135.3,138.6,140.6,142.7,154.1,164.4$. This material was pure by TLC ( silica gel).

6-Iodo- $\beta$-carboline-3,9-dicarboxylic acid di-tert-butyl ester (35). To a solution of 6-iodo- $\beta$ carboline-3-carboxylic acid t-butyl ester $5(2 \mathrm{~g}, 5.06 \mathrm{mmol})$ in anhydrous $\mathrm{CH}_{2} \mathrm{Cl}_{2}(30 \mathrm{~mL})$, (Boc) $)_{2} \mathrm{O}$ $(1.32 \mathrm{~g}, 6.07 \mathrm{mmol})$ and DMAP $(123 \mathrm{mg}, 1.01 \mathrm{mmol})$ were added. The reaction mixture was allowed to stir at rt for half an hour until analysis by TLC (silica gel) indicated that the starting material had been converted into the Boc protected indole 35. The solvent was removed under reduced pressure and the residue was purified by flash chromatography (silica gel, EtOAc/hexane = 5:95) to provide 35 (2.3 g, 92\%) as a white solid. 35: $\mathrm{mp} 317-320^{\circ} \mathrm{C}$; IR (NaCl) 2975, 2917, 1728, 1457, 1343, 1238, 1154, 1119 , $1031,811 \mathrm{~cm}^{-1} ;{ }^{1} \mathrm{H}$ NMR $\left(300 \mathrm{MHz}, \mathrm{CDCl}_{3}\right) \delta 1.71(\mathrm{~s}, 9 \mathrm{H}), 1.77(\mathrm{~s}, 9 \mathrm{H}), 7.91(\mathrm{~d}, J=8.972 \mathrm{~Hz}, 1 \mathrm{H})$, $8.22(\mathrm{~d}, J=8.972 \mathrm{~Hz}, 1 \mathrm{H}), 8.42(\mathrm{~s}, 1 \mathrm{H}), 8.61(\mathrm{~s}, 1 \mathrm{H}), 9.61(\mathrm{~s}, 1 \mathrm{H}) ;{ }^{13} \mathrm{C} \mathrm{NMR}\left(300 \mathrm{MHz}, \mathrm{CDCl}_{3}\right) \delta 28.1$ 28.2, 82.1 $85.8,87.2,115.9,118.5,125.7,129.9,130.6,135.7,138.9,143.0149 .6164 .1 ; \mathrm{MS}(\mathrm{EI}) \mathrm{m} / \mathrm{e}$ (relative intensity) $494\left(\mathrm{M}^{+}, 42\right), 438$ (71), 338 (100), 294 (70), 268 (8), 212 (8), 168 (35). Anal. calcd. for $\mathrm{C}_{21} \mathrm{H}_{23} \mathrm{IN}_{2} \mathrm{O}_{4}\left(0.1 \mathrm{C}_{6} \mathrm{H}_{14}\right)$ : C, 51.60; H, 4.85; N, 5.57; Found: C, 51.84; H, 4.88; N: 5.45 . 


\section{6-Trimethylsilanylethynyl- $\beta$-carboline-3,9-dicarboxylic acid di-tert-butyl ester (36).}

Dichlorobis(triphenylphosphine)palladium(II) (140 mg; $2 \mathrm{~mol} \%$ ), and CuI (40 mg; $2 \mathrm{~mol} \%$ ) were added to a solution of 6-iodo- $\beta$-carboline-3,9-dicarboxylic acid di-tert-butyl ester 35 (4.9 g; $10 \mathrm{mmol})$ in anhydrous THF $(30 \mathrm{~mL})$ and triethylamine $(10 \mathrm{~mL})$. The mixture was degassed, and back-filled three times with argon. Then (trimethylsilyl) acetylene $(1.08 \mathrm{~g} ; 11 \mathrm{mmol})$ was added with stirring under argon. After the mixture was allowed to stir for $1 \mathrm{~h}$, the solvents were removed in vacuum and the residue was chromatographed on a short column (silica gel, hexane/ $\mathrm{CH}_{2} \mathrm{Cl}_{2}=7: 3$ ) to give 36 (4.36 $\mathrm{g}$, 94\%) as a white solid. 36: $\mathrm{mp} 334-336^{\circ} \mathrm{C}(\mathrm{dec})$; IR (NaCl) 2974, 2137, 1732, 1559, 1476, 1469, 1368 , 1343, 1309, 1247, 1156, 1109, 872, 842, $760 \mathrm{~cm}^{-1} ;{ }^{1} \mathrm{H}$ NMR (300 MHz, $\left.\mathrm{CDCl}_{3}\right) \delta 0.31(\mathrm{~s}, 9 \mathrm{H}), 1.71$ (s, 9H), $1.78(\mathrm{~s}, 9 \mathrm{H}), 7.77(\mathrm{~d}, 2 \mathrm{H}, \mathrm{J}=8.97), 8.25(\mathrm{~s}, 1 \mathrm{H}), 8.41(\mathrm{~d}, 2 \mathrm{H}, \mathrm{J}=8.61), 8.65(\mathrm{~s}, 1 \mathrm{H}), 9.62(\mathrm{~s}, 1 \mathrm{H}) ;{ }^{13} \mathrm{C}$ $\operatorname{NMR}\left(300 \mathrm{MHz}, \mathrm{CDCl}_{3}\right) \delta 0.11,28.1,28.2,82.1,85.8,94.4,104.4,116,116.5,118.7,123.5,124.7$, 131.6, 133.7, 136.2, 138.1, 139.2, 142.9, 149.7, 164.1; MS (EI) m/e (relative intensity) $465\left(\mathrm{M}^{+}, 30\right)$, 409 (100), 365 (21), 308 (80), 262 (25), 249 (40). Anal. calcd. for $\mathrm{C}_{26} \mathrm{H}_{32} \mathrm{~N}_{2} \mathrm{O}_{4}$ Si: C, 67.21; H, 6.94; N, 6.03; O, 13.77; Si, 6.04. This material was pure by TLC (silica gel) and used in the next step.

6-Ethynyl- $\beta$-carboline-3,9-dicarboxylic acid di-tert-butyl ester 34: To a solution of 6trimethylsilanylethynyl- $\beta$-carboline-3,9-dicarboxylic acid di-tert-butyl ester $36(2.14 \mathrm{~g}, 4.6 \mathrm{mmol})$ in THF (20 mL), $1.2 \mathrm{eq}$ of TBAF (5.52 $\mathrm{ml}$ of $1 \mathrm{M}$ TBAF/THF solution) at $0{ }^{\circ} \mathrm{C}$ was added and then the solution was allowed to warm to rt. After consumption of the starting material as indicated by TLC (silica gel), $\mathrm{H}_{2} \mathrm{O}(10 \mathrm{~mL})$ was added and the mixture was extracted with $\mathrm{CH}_{2} \mathrm{Cl}_{2}(20 \mathrm{~mL}, 3 \mathrm{X})$. The combined organic layer was concentrated under reduced pressure and the residue was chromatographed on a short column ( 226-229 ${ }^{\circ} \mathrm{C}$; IR (NaCl) 3303, 2978, 2346, 2232, 1734, 1622, 1560, 1463, 1394, 1310, 1248, 1151, 1110, 1031, 911, 836, $731 \mathrm{~cm}^{-1} ;{ }^{1} \mathrm{H}$ NMR $\left(300 \mathrm{MHz}, \mathrm{CDCl}_{3}\right) \delta 1.54(\mathrm{~s}, 9 \mathrm{H}), 1.72(\mathrm{~s}, 9 \mathrm{H}), 1.79(\mathrm{~s}, 9 \mathrm{H}), 3.17(\mathrm{~s}$, $1 \mathrm{H}), 7.79(\mathrm{~d}, 2 \mathrm{H}, \mathrm{J}=8.76), 8.27(\mathrm{~s}, 1 \mathrm{H}), 8.44(\mathrm{~d}, 2 \mathrm{H}, \mathrm{J}=8.94), 8.67(\mathrm{~s}, 1 \mathrm{H}), 9.64(\mathrm{~s}, 1 \mathrm{H}) ;{ }^{13} \mathrm{C}$ NMR $(75.5$ 
$\left.\mathrm{MHz}, \mathrm{CDCl}_{3}\right) \delta 27.3,28.1,28.2,67.8,82.1,83.0,85.1,85.5,116.0,116.7,123.5,124.9,133.7,136.2$,

138.1, 139.4, 143.0, 164.2; MS (EI) m/e (relative intensity) $393\left(\mathrm{M}^{+}, 32\right), 338$ (13), 321 (26), 293 (100),

167 (28), 139 (24). Anal. Calcd. for $\mathrm{C}_{23} \mathrm{H}_{24} \mathrm{~N}_{2} \mathrm{O}_{4}\left(0.05 \mathrm{CH}_{2} \mathrm{Cl}_{2}\right)$ : C, 69.78; H, 6.12; N, 7.06; Found: C: 69.70; H: 6.10; N: 6.81 .

1,2-Bis(9H- $\beta$-carboline-3-carboxylic acid tert-butyl ester) ethyne (32). Dichlorobis (triphenylphosphine)palladium(II) (60 mg, $2 \mathrm{~mol} \%)$ and copper iodide (16 mg, $2 \mathrm{~mol} \%$ ) were added to a mixture of 6-ethynyl- $\beta$-carboline-3,9-dicarboxylic acid di-tert-butyl ester 34 (1.6g, 4.1mmol) and 6iodo- $\beta$-carboline-3,9-dicarboxylic acid di-tert-butyl ester 35 (2.1g, 4.25mmol) in THF/ TEA(30 mL; 4:1). The reaction mixture which resulted was degassed, and back-filled three times with argon. The reaction mixture was then allowed to stir at $\mathrm{rt}$ for about $1 \mathrm{~h}$ until analysis by TLC (silica gel) indicated the starting materials were absent. The solution was concentrated under reduced pressure and the residue was chromatographed on a silica gel column with $\mathrm{CH}_{2} \mathrm{Cl}_{2}$ as the eluent to give $1,2-\mathrm{Bis}(\beta$ carboline-3,9-dicarboxylic acid di-tert-butyl ester) ethyne (2.97 g, 95\%) as a white solid: mp 305-307 ${ }^{\circ} \mathrm{C}$; IR (NaCl) 2972, 2929, 1737, 1559, 1466, 1338, 1156, 1102, 823, 624cm ${ }^{-1} ;{ }^{1} \mathrm{H}$ NMR $(300 \mathrm{MHz}$, $\left.\mathrm{CDCl}_{3}\right) \delta 1.72(\mathrm{~s}, 9 \mathrm{H}), 1.79(\mathrm{~s}, 9 \mathrm{H}), 7.86(\mathrm{~d}, J=8.97 \mathrm{~Hz}, 1 \mathrm{H}), 8.32(\mathrm{~s}, 1 \mathrm{H}), 8.47(\mathrm{~d}, J=8.79 \mathrm{~Hz}, 1 \mathrm{H})$, $8.68(\mathrm{~s}, 1 \mathrm{H}), 9.63(\mathrm{~s}, 1 \mathrm{H}) ;{ }^{13} \mathrm{C} \mathrm{NMR}\left(300 \mathrm{MHz}, \mathrm{CDCl}_{3}\right) \delta 28.2,82.1,85.8,89.0,116.0,116.7,118.6$, 123.6, 124.3, 131.5, 133.3, 136.1, 138.1, 139.1, 143.0, 149.7, 164.2; MS (FAB) 759(M+1 13). Anal. calcd. for $\mathrm{C}_{44} \mathrm{H}_{46} \mathrm{~N}_{4} \mathrm{O}_{8}\left(\mathrm{H}_{2} \mathrm{O}\right)$ : C, 68.03; H, 6.22; N, 7.21; Found: C: 68.10; H: 6.22; N: 7.21 .

The 1,2-bis( $\beta$-carboline-3,9-dicarboxylic acid di-tert-butyl ester) ethyne (800mg, $1.05 \mathrm{mmol})$ was added to a distilled solution of cumene $(40 \mathrm{~mL})$, which had been degassed. The reaction vessel was evacuated and refilled with nitrogen three times. The temperature was then brought to reflux for about $30 \mathrm{~min}$ until a yellow precipitate had formed. The mixture which resulted was filtered and washed with hexane to give pure dimer 32 (545 mg, 93\%). 32: m.p. >350 ${ }^{\circ} \mathrm{C}$ (dec.); IR (KBr) 3227, 1716, 1327, 1162, 738, $450 \mathrm{~cm}^{-1} ;{ }^{1} \mathrm{H}$ NMR (300 MHz, DMSO) $\delta 1.62$ (s, 9H), 7.70-7.80 (m, 2H), $8.7(\mathrm{~s}, 1 \mathrm{H}), 8.94(\mathrm{~s}, 1 \mathrm{H}), 8.99$ 
$(\mathrm{s}, 1 \mathrm{H}), 12.25(\mathrm{~s}, 1 \mathrm{H}) ;{ }^{13} \mathrm{C} \mathrm{NMR}\left(300 \mathrm{MHz}, \mathrm{CDCl}_{3}\right) \delta 28.3,80.8,113.3,114.6,117.9,125.8,127.5$, 131.9, 134.2, 138.0, 140.8, 164.9; MS (FAB) 559(M+, 41). This material was pure by TLC (silica gel).

1,4-Bis(9H- $\beta$-carboline-3-carboxylic acid tert-butyl ester) buta-1,3-diyne (33). In a round bottom flask (200 mL), $\mathrm{PdCl}_{2}\left(\mathrm{PPh}_{3}\right)_{2}(58 \mathrm{mg}, 2 \mathrm{~mol} \%), \mathrm{CuI}(16 \mathrm{mg}, 2 \mathrm{~mol} \%)$, and diisopropylethylamine (534 mg, $4.92 \mathrm{mmol}$ ) were added and the mixture stirred under argon. The flask was evacuated (degassed) and refilled with argon. The THF (40 mL) and 6-ethynyl- $\beta$-carboline-3,9-dicarboxylic acid di-tert-butyl ester $34(1.6 \mathrm{~g}, 4.1 \mathrm{mmol})$ were then added (under argon) to the above mixture. To this flask methyl bromoacetate $(410 \mathrm{mg}, 2.5 \mathrm{mmol}$ ) was added, and the reaction mixture was stirred at $\mathrm{rt}$ for 6-8 h. The progress of this reaction was monitored by TLC on silica gel. After the reaction was complete, 8-10 g of silica gel was added and the solvent was removed under vacuum. The solid residue (a plug) was then placed on a column and subjected to column chromatography $\left(\mathrm{CH}_{2} \mathrm{Cl}_{2}\right)$ to give 1,4$\operatorname{Bis}\left(\beta\right.$-carboline-3,9-dicarboxylic acid di-tert-butyl ester) buta-1,3-diyne $(2.08 \mathrm{~g}, 65 \%):{ }^{1} \mathrm{H}$ NMR $\left(300 \mathrm{MHz} \mathrm{CDCl}_{3}\right) \delta 1.74(\mathrm{~s}, 9 \mathrm{H}), 1.81(\mathrm{~s}, 9 \mathrm{H}), 7.82(\mathrm{~d}, J=8.79 \mathrm{~Hz}, 1 \mathrm{H}), 8.34(\mathrm{~s}, 1 \mathrm{H}), 8.48(\mathrm{~d}, J=8.79 \mathrm{~Hz}$, 1H), 8.69(s, 1H), 9.65(s, 1H); ${ }^{13} \mathrm{C} \mathrm{NMR}\left(300 \mathrm{MHz}, \mathrm{CDCl}_{3}\right) \delta 28.2,74.0,81.2,82.2,86.0,116.1,116.9$, $117.2,123.7,125.5,131.3,134.0,136.2,138.1,139.6,143.2,149.6,164.1$; MS (FAB) 783(M+, 100). Anal. Calcd. for $\mathrm{C}_{46} \mathrm{H}_{46} \mathrm{~N}_{4} \mathrm{O}_{8} \cdot 1.5 \mathrm{H}_{2} \mathrm{O}: \mathrm{C}, 68.22 ; \mathrm{H}, 6.10 ; \mathrm{N}, 6.91$; Found: C: 68.49; H: 5.87; N: 6.58.

The 1,4-Bis-( $\beta$-carboline-3,9-dicarboxylic acid di-tert-butyl ester) buta-1,3-diyne (411 $\mathrm{mg}, 0.5 \mathrm{mmol})$ was added to a distilled solution of cumene $(20 \mathrm{~mL})$, which had been degassed. The reaction mixture was evacuated and refilled with nitrogen three times. The temperature was then brought to reflux for about 30 min until a yellow precipitate had formed. The mixture was filtered and the solids washed with hexane to give pure dimer 33. 33: $\mathrm{mp}>350{ }^{\circ} \mathrm{C}$ (dec.) $\operatorname{IR}(\mathrm{KBr}) 3424,1708,1627,1466,1369,1302$,

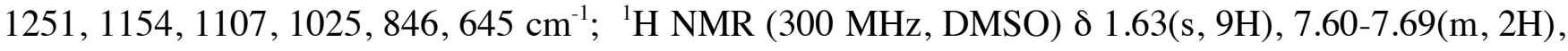
8.40(s, 1H), 8.96(s, 1H), 9.04(s, 1H), 12.5(s, 1H); ${ }^{13} \mathrm{C} \mathrm{NMR}\left(300 \mathrm{MHz}, \mathrm{CDCl}_{3}\right) \delta 28.3,78.8,82.5,112.9$, $118.1,121.0,122.1,129.5,131.5,134.8,141.1,163.0,131.9,134.2,138.0,140.8,164.9 ;$ MS (FAB) 


\section{Acknowledgement}

This work was supported in part by NIMH 46851 (J.M.C.). We acknowledge support of this work by the Research Growth Initiative of the University of Wisconsin - Milwaukee and the Lynde and Harry Bradley Foundation.

1. Cook, J. M.; Han, D.; Clayton, T. GABAergic agents to treat memory deficits. US 2006/0258643 A1. 2006.

2. Harvey, S. C.; Foster, K. L.; McKay, P. F.; Carroll, M. R.; Seyoum, R.; Woods, J. E.; Grey, C.; Jones, C. M.; McCane, S.; Cummings, R.; Mason, D.; Ma, C. R.; Cook, J. M.; June, H. L. The GABA(A) receptor alpha(1) subtype in the ventral pallidum regulates alcohol-seeking behaviors. $J$. Neurosci. 2002, 22, 3765-3775.

3. June, H. L.; Foster, K. L.; Mc Kay, P. F.; Seyoum, R.; Woods, J. E. I.; Harvey, S. C.; Eiler, W. J. A. I.; Grey, C.; Caroll, M. E.; Mc Cane, S.; Jones, C. M.; Yin, W.; Mason, D.; Cumings, R.; Garcia, M.; Sarma, P.; Cook, J. M.; Skolnick, P. The reinforcing properties of alcohol are mediated by GABA $\alpha_{1}$ receptors in the ventral palladium. Neuropsychopharmacol. 2003, 1-14.

4. Kessler, R. C.; Frank, R. G. The Impact of psychiatric disorders on work loss days. Psychiatric Medicine 1997, 27, 861-873.

5. O'Malley, S. S.; A.J., J.; Chang, G.; Schottenfeld, R. S.; Meyer, R. E.; Rounsaville, B. Naltrexone and coping skills therapy for alcohol dependence: A controlled Study. Arch Gen Psychiatry 1992, 49, 881-887.

6. Volpicelli, J. R.; Alterman, A. I.; Hayashida, M.; O'brien, C. P. Naltrexone and the treatment of alcohol abuse. Arch Gen Psychiatry 1992, 49, 876-880.

7. Kranzler, H. R. Pharmacotherapy of alcoholism: Gaps in knowledge and opportunities for research. Alcohol 2000, 35, 537-547.

8. Spanagel, R.; Zieglgansberger, W. Anti-craving compounds for ethanol: New pharmacological tool to study addictive processes. Trends Pharmacol. Sci. 1997, 18. 
9. Cloninger. Neurogenetic adaptive mechanisms in alcoholism. Science 1987, 236, 410-416.

10. Li, T.-K. Pharmacogenics of responses to alcohol and genes that influence alcohol drinking. $J$ Stud Alcohol 2000, 61, 5-12.

11. Li, T.-K.; D.W., C.; Lumeng, L. Neuropharmacology of Ethanol. Birkhauser: Boston, 1991; p 107-124.

12. Johnson, B. A.; Ait-Daoud, N. Neuropharmacological treatments for alcoholism: scientific basis and clinical findings. Psychopharmacology 2000, 149, 327-344.

13. Koob, G. F.; Roberts, A. J. Neurocircutry targets in ethanol reward and dependence. Alcoholism: Clin Exper Res 1998, 22, 3-9.

14. June, H. L.; Cason, C. R.; Cheatham, G.; Lui, R. Y.; Gan, T.; Cook, J. M. GABA(A)benzodiazepine receptors in the striatum are involved in the sedation produced by a moderate, but not an intoxicating ethanol dose in out-bred Wistar rats. Brain Research 1998, 794, 103-118.

15. McBride, W. J.; Li, T. Animal models of alcoholism: Neurobiology of high alcohol-drinking behavior in rodents. Critical Reviews in Neurobiology 1998, 12, 339-369.

16. Allain, H.; Belliard, S.; Decertaines, J.; Bentueferrer, D.; Bureau, M.; Lacroix, P. Potential Biological Targets for Anti-Alzheimer Drugs. Dementia 1993, 4, 347-352.

17. Heimer, L.; Alheid, G. F. The basal forebrain: anatomy and function. Plenum Press: New York, 1991; p 1-42.

18. Heimer, L.; Zahm, D. S.; Churchill, P.; Kalivas, W. Specificity in the projection patterns of accumbal core and shell in the rat. Neuroscience 1991, 41, 89-125.

19. Criswell, H. E.; Simson, P. E.; Duncan, G. E.; Mc Cown, T. J.; Herbert, J. S.; Morrow, L. Molecular Basis for Regionally Specific Action of Ethanol on $\gamma$-Aminobutyric Acida Receptors: Generalization to Other Ligand-Gated Ion Channels. J. Pharmacol. Exper. Ther. 1993, 267, 522-527.

20. Criswell, H. E.; Simson, P. E.; Knapp, D. J.; Devaud, L. L.; Mc Cown, T. J.; Duncan, G. E. Effect of Zolpidem on $\gamma$-Aminobutyric Acid (GABA)-Induced Inhibition Predicts the Interaction of Ethanol with GABA on Individual Neurons in Several Rat Brain Regions. J. Pharmacol. Exper. Ther. 1995, 273, 525-536.

21. June, H. L.; Zuccarelli, D.; Torres, L.; Craig, K. S.; DeLong, J.; Allen, A.; Braun, M. R.; Cason, C. R.; Murphy, J. M. High-affinity benzodiazepine antagonists reduce responding maintained by ethanol presentation in ethanol-preferring rats. J. Pharmacol. Exp. Ther. 1998, 284, 1006-1014.

22. June, H. L.; Harvey, S. C.; Foster, K. L.; McKay, P. F.; Cummings, R.; Garcia, M.; Mason, D.; Grey, C.; McCane, S.; Williams, L. S.; Johnson, T. B.; He, X. H.; Rock, S.; Cook, J. M. GABA(A) receptors containing alpha 5 subunits in the CA1 and CA3 hippocampal fields regulate ethanolmotivated behaviors: An extended ethanol reward circuitry. J. Neurosci. 2001, 21, 2166-2177.

23. Hyytia, P.; Koob, G. F. GABA(A) receptor antagonism in the extended amygdala decreases ethanol self-administration in rats. Eur J Pharmacol 1995, 283, 151-159.

24. Nowak, K. L.; McBride, W. J.; Lumeng, L.; Li, T.-K.; Murphy, J. M. Blocking GABA(A) receptors in the anterior ventral tegmental area attenuates ethanol intake of the alcohol preferring $\mathrm{P}$ rat. Psychopharmacology 1998, 139, 108-116.

25. Nauta, H. J.; Smith, G. P.; Faull, R. L. M.; Domesick, V. B. Efferent connections and nigral afferents of the nucleus accumbens septi in the rat. Neuroscience 1978, 3.

26. Zahm, D. S.; Heimer, L. Ventral striatopallidal parts of the basal ganglia in the rat: I. Neurochemical compartmentation as reflected by the distributions of neurotensin and substance $\mathrm{P}$ immunoreactivity. J. Comp Neurol 1988, 272, 516-535.

27. Groenwegen, H. J.; Berende, H. W. Organization of the output of the ventral striatopallidal system in the rat: Ventral pallidal efferents. Neuroscience 1993, 57, 113-142.

28. Churchill, L.; Kalivas, P. W. A topographical organized GABA projection from the ventral pallidum to the nucleus accumbens in the rat. J Comp Neurol 1994, 345, 579-595.

29. Kuo, H.; Chang, H. T. Ventral-pallidostriatal pathway in the rat brain: A light electron microscopic study. J Comp Neurol 1992, 321, 626-636.

30. Morgenson, G. J.; Nielson, M. Evidence that an accumbens to subpallidal GABAergic projection contributes to locomotor activity. Brain Res Bulletin 1983, 11, 309-314.

31. Fritschy, J. M.; Mohler, H. Gaba(a)-Receptor Heterogeneity in the Adult-Rat Brain - Differential 
Regional and Cellular-Distribution of 7 Major Subunits. Journal of Comparative Neurology 1995, 359, 154-194.

32. Turner, J. D.; Bodewitz, G.; Thompson, C. L.; Stephenson, F. A. Anxiolytic Beta carbolines: from molecular biology to the clinic. Springer-Verlag: New York, 1993; p 29-49.

33. Churchill, L.; Bourdelais, A.; Austin, S.; Lolait, S. J.; Mahan, L. C.; O'Carroll, A. M.; Kalivas, P. W. GABA(A) receptors containing alpha1 and alpha2 subunits are mainly localized on neurons in the ventral pallidum. Synapes 1991, 8, 75-85.

34. Wisden, W.; Laurie, D. J.; Monyer, H.; Seeburg, P. H. The Distribution of 13-Gaba-a Receptor Subunit Messenger-Rnas in the Rat-Brain .1. Telencephalon, Diencephalon, Mesencephalon. $J$. Neurosci. 1992, 12, 1040-1062.

35. Duncan, G. E.; Breese, G. R.; Criswell, H. E.; McCown, T. J.; Herbert, J. S.; Devaud, L. L.

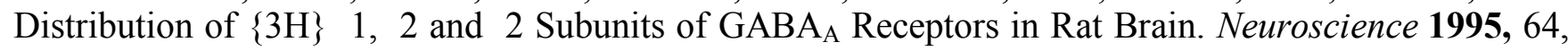
1113-1128.

36. Napier, T. C.; Chrobak, J. J. Evaluation of ventral pallidal dopamine receptor activation in behaving rats. Neuroreport 1992, 3, 609-611.

37. Hubner, C. B.; Koob, G. F. GABA(A) receptor antagonism in the extended amygdala decreases ethanol self-administration in rats. Eur J Pharmacol 1995, 283, 151-159.

38. Gong, W.; Justice, J. B. Dissociation of locomotor and conditioned place preference responses following manipulation of GABA-A and AMPA receptors in ventral pallidum. Prog Neuropsychohpharmacol Bio Psych 1997, 21, 839-852.

39. Gong, W.; Neill, D. Place preference conditioning and locomotor activation induced by local injection of psychostimulants into ventral pallidum. Brain Res 1996, 707, 64-74.

40. Cicero, T. J. Biochemistry and Pharmacology of Ethanol. Plenum Press: New York, 1979; Vol. 2, p 533-560.

41. Lumeng, L.; Murphy, J. M.; McBride, W. J.; Li, T.-K. Genetic Influences on alcohol preference in animals. Oxford University Press: New York, 1995; p 165-201.

42. Duncan, G. E.; Breese, G. R.; Criswell, H. E.; McCown, T. J.; Herbert, J. S.; Devaud, L. L.; Morrow, A. L. Distribution of [H-3] Zolpidem Binding-Sites in Relation to Messenger-Rna Encoding the Alpha-1, Beta-2 and Gamma-2 Subunits of Gaba(a) Receptors in Rat-Brain. Neuroscience 1995, 64, 1113-1128.

43. June, H. L.; Eggers, M. W.; Warren-Reese, C.; DeLong, J.; Ricks-Cord, A.; Durr, L. F.; Cason, C. R. The effects of the novel benzodiazepine receptor inverse agonist $\mathrm{Ru} 34000$ on ethanol-maintained behaviors. Eur. J. Pharmacol. 1998, 350, 151-158.

44. June, H. L.; Torres, L.; Cason, C. R.; Hwang, B. H.; Braun, M. R.; Murphy, J. M. The novel benzodiazepine inverse agonist RO19-4603 antagonizes ethanol motivated behaviors: neuropharmacological studies. Brain Research 1998, 784, 256-275.

45. Sieghart, W.; Ernst, M. Heterogeneity of GABAA Receptors: Revived Interest in the Development of Subtype-selective Drugs. Curr. Med. Chem.: Cent. Nerv. Syst. Agents 2005, 5, $217-$ 242.

46. Bowser, D. N.; Wagner, D. A.; Czajkowski, C.; Cromer, B. A.; Parker, M. W.; Wallace, R. H.; Harkin, L. A.; Mulley, J. C.; Marini, C.; Berkovic, S. F.; Williams, D. A.; Jones, M. V.; Petrou, S. Altered kinetics and benzodiazepine sensitivity of a $\mathrm{GABA}_{\mathrm{A}}$ receptor subunit mutation $[\gamma 2(\mathrm{R} 43 \mathrm{Q})]$ found in human epilepsy. Proc. Natl. Acad. Sci. U.S.A. 2002, 99, 15170-15175.

47. Bateson, A. N. The benzodiazepine site of the $\mathrm{GABA}_{\mathrm{A}}$ receptor: An old target with new potential? Sleep Medicine 2004, 5, S9-S15.

48. Otani, K.; Ujike, H.; Tanaka, Y.; Morita, Y.; Katsu, T.; Nomura, A.; Uchida, N.; Hamamura, T.; Fujiwara, Y.; Kuroda, S. The GABA type A receptor alpha 5 subunit gene is associated with bipolar I disorder. Neuroscience Letters 2005, 381, 108-113.

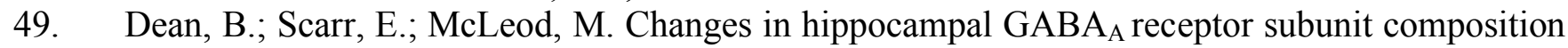
in bipolar I disorder. Brain Res. Mol. Brain Res. 2005, 138, 145-155.

50. Guidotti, A.; Auta, J.; Davis, J. M.; Dong, E. B.; Grayson, D. R.; Veldic, M.; Zhang, X. Q.; Costa, E. GABAergic dysfunction in schizophrenia: new treatment strategies on the horizon. Psychopharmacology 2005, 180, 191-205. 
51. Maubach, K. GABA $\mathrm{A}_{\mathrm{A}}$ receptor subtype selective cognition enhancers. Drug Targets-CNS \& Neuro. Disorders 2003, 2, 233-239.

52. Barrett, A. C.; Negus, S. S.; Mello, N. K.; Caine, S. B. Effect of GABA agonists and GABA-A receptor modulators on cocaine- and food-maintained responding and cocaine discrimination in rats. $J$. Pharmacol. Exp. Ther. 2005, 315, 858-871.

53. Anthenelli, R.; Schuckit, M. A. Genetic studies in alcoholism. International Journal of Addict. 1990/1991, 25, 81-94.

54. Schuckit, M. A. Reactions to alcohol in sons of alcoholics and controls. Alcohol Clin. Exp. Res. 1988, 12, 465-470.

55. Barnard, E. A.; Skolnick, P.; Olsen, R. W.; Möhler, H.; Sieghart, W.; Biggio, G.; Braestrup, C.; Bateson, A. N.; Langer, S. Z. International Union of Pharmacology. XV. Subtypes of $\gamma$-aminobutyric acidA receptors: classification on the basis of subunit structure and function. Pharmacol. Rev. 1998, 50, 291-313.

56. Simon, J.; Wakimoto, H.; Fujita, N.; Lalande, M.; Barnard, E. A. Analysis of the set of GABA(A) receptor genes in the human genome. J. Biol. Chem. 2004, 279, 41422-41435.

57. Sieghart, W.; Sperk, G. Subunit composition, distribution and function of $\mathrm{GABA}_{\mathrm{A}}$ receptor subtypes. Curr. Top. Med. Chem. 2002, 2, 795-816.

58. Mossier, B.; Togel, M.; Fuchs, K.; Sieghart, W. Immunoaffinity Purification of GammaAminobutyric Acid(a) (Gaba(a)) Receptors Containing Gamma(1)-Subunits - Evidence for the Presence of a Single Type of Gamma-Subunit in Gaba(a) Receptors. J. Biol. Chem. 1994, 269, 25777-25782.

59. Togel, M.; Mossier, B.; Fuchs, K.; Sieghart, W. Gamma-Aminobutyric Acid(a) Receptors Displaying Association of Gamma(3)-Subunits with Beta(2/3) and Different Alpha-Subunits Exhibit Unique Pharmacological Properties. J. Biol. Chem. 1994, 269, 12993-12998.

60. Pirker, S.; Schwarzer, C.; Wieselthaler, A.; Sieghart, W.; Sperk, G. GABA(A) receptors: Immunocytochemical distribution of 13 subunits in the adult rat brain. Neuroscience 2000, 101, 815850 .

61. Cox, E. D.; Diaz-Arauzo, H.; Huang, Q.; Reddy, M. S.; Ma, C. R.; Harris, B.; McKernan, R.; Skolnick, P.; Cook, J. M. Synthesis and evaluation of analogues of the partial agonist 6-(propyloxy)-4(methoxymethyl)-beta-carboline-3-carboxylic acid ethyl ester (6-PBC) and the full agonist 6(benzyloxy)-4-(methoxymethyl)-beta-carboline-3-carboxylic acid ethyl ester (Zk 93423) at wild type and recombinant GABA(A) receptors. J. Med. Chem. 1998, 41, 2537-2552.

62. Huang, Q.; He, X. H.; Ma, C. R.; Liu, R. Y.; Yu, S.; Dayer, C. A.; Wenger, G. R.; McKernan, R.; Cook, J. M. Pharmacophore/receptor models for $\mathrm{GABA}_{\mathrm{A}} / \mathrm{BzR}$ subtypes $(\alpha 1 \beta 3 \gamma 2, \alpha 5 \beta 3 \gamma 2$, and $\alpha 6 \beta 3 \gamma 2$ ) via a comprehensive ligand-mapping approach. J. Med. Chem. 2000, 43, 71-95.

63. Carroll, M.; Woods II, J. E.; Seyoum, R. A.; June, H. L. The role of the GABA(A) alpha1 subunit in mediating the sedative and anxiolytic properties of benzodiazepines. Alcohol Clin Exp Res 2001, 25.

64. Rowlett, J. K. unpublished. 2010.

65. June, H. L.; Cook, J. M.; Ma, C. R. Methods for reducing alcohol cravings in chronic alcoholics. 2003.

66. Foster, K. L.; McKay, P. F.; Seyoum, R.; Milbourne, D.; Yin, W.; Sarma, P. S.; Cook, J. M.; June, H. L. GABA(A) and opioid receptors of the central nucleus of the amydgala selectively regulate ethanol-maintained behaviors. Neuropsychopharmacol 2004, 29, 269-284.

67. Araki, T.; Tohyama, M. Region-specific expression of GABA(A) receptor alpha 3 and alpha 4 subunits mRNAs in the rat brain. . Mol Brain Res 1992, 12, 295-314.

68. Cox, E. D.; Hagen, T. J.; McKernan, R. M.; Cook, J. M. Bz(1) receptor subtype specific ligands. Synthesis and biological properties of $\mathrm{BCCt}, \mathrm{a} \mathrm{Bz}(1)$ receptor subtype specific antagonist. Med. Chem. Res. 1995, 5, 710-718.

69. Griebel, G.; Perrault, G.; Letang, V.; Granger, P.; Avenet, P.; Schoemaker, H.; Sanger, D. J. New evidence that the pharmacological effects of benzodiazepine receptor ligands can be associated with activities at different BZ (omega) receptor subtypes. Psychopharmacology 1999, 146, 205-213.

70. Carroll, M. E.; Carmona, G.; May, S. Modifying drug-reinforced behavior by altering the economic conditions of the drug and the drug reinforcer. J Exp Anal Behav 1991, 18, 361-376. 
71. Paronis, C. A.; Cox, E. D.; Cook, J. M.; Bergman, J. Different types of GABA(A) receptors may mediate the anticonflict and response rate-decreasing effects of zaleplon, zolpidem, and midazolam in squirrel monkeys. Psychopharmacology 2001, 156, 461-468.

72. Rowlett, J. K.; Tornatzky, W.; Cook, J. M.; Ma, C. R.; Miczek, K. A. Zolpidem, triazolam, and diazepam decrease distress vocalizations in mouse pups: Differential antagonism by flumazenil and beta-carboline-3-carboxylate-t-butyl ester (beta-CCt). J. Pharmacol. Exp. Ther. 2001, 297, 247-253.

73. Shannon, H. E.; Guzman, F.; Cook, J. M. Carboline-3-carboxylate-t-butyl ester: a selective BZ1 benzodiazepine receptor antagonist. Life Sci. 1984, 35, 2227-2236.

74. Rowlett, J. K.; Spealman, R. D.; Lelas, S.; Cook, J. M.; Yin, W. Y. Discriminative stimulus effects of zolpidem in squirrel monkeys: role of $\mathrm{GABA}(\mathrm{A}) /($ alpha 1) receptors. Psychopharmacology 2003, 165, 209-215.

75. Cox, E. D.; Hagen, T. J.; Mckernan, R. M.; Cook, J. M. Bz(1) receptor subtype specific ligands. Synthesis and biological properties of $\mathrm{BCCt}, \mathrm{a} \mathrm{Bz}(1)$ receptor subtype specific antagonist. Med. Chem. Res. 1995, 5, 710-718.

76. Rowlett, J. K.; Cook, J. M.; Duke, A. N.; Platt, D. M. Selective antagonism of GABA(A) receptor subtypes: An in vivo approach to exploring the therapeutic and side effect of benzodiazepinetype drugs. CNS Spectrums 2005, 10, 40-48.

77. Liu, R.; Zhang, P.; Mckernan, R. M.; Wafford, K. A.; Cook, J. M. Synthesis of novel imidazobenzodiazepines selective for the $\alpha 5 \beta 2 \gamma 2\left(\mathrm{Bz}_{5}\right) \mathrm{GABA}_{\mathrm{A}} /$ benzodiazepine receptor subtype. Med. Chem. Res. 1995, 5, 700-709.

78. Liu, R.; Hu, R. J.; Zhang, P.; Skolnick, P.; Cook, J. M. Synthesis and pharmacological properties of novel 8-substituted imidazobenzodiazepines: High-affinity, selective probes for $\alpha 5$-containing GABA $_{\mathrm{A}}$ receptors. J. Med. Chem. 1996, 39, 1928-1934.

79. Li, X. Y.; Cao, H.; Zhang, C. C.; Furtmueller, R.; Fuchs, K.; Huck, S.; Sieghart, W.; Deschamps, J.; Cook, J. M. Synthesis, in vitro affinity, and efficacy of a bis 8-ethynyl-4H-imidazo[1,5a]$[1,4]$ benzodiazepine analogue, the first bivalent alpha 5 subtype selective BzR/GABA(A) antagonist. $J$. Med. Chem. 2003, 46, 5567-5570.

80. $\quad$ Allen, M. S.; Tan, Y. C.; Trudell, M. L.; Narayanan, K.; Schindler, L.; Martin, M. J.; Schultz, C. A.; Hagen, T. J.; Koehler, K. F.; Codding, P.; Skolnick, P.; Cook, J. Synthetic and computer-assisted analyses of the pharmacophore for the benzodiazepine receptor inverse agonist site. J. Med. Chem. 1990, 33, 2343-2357.

81. Allen, M. S.; Laloggia, A. J.; Dorn, L. J.; Martin, M. J.; Constantino, G.; Hagen, T. J.; Koehler, K. F.; Skolnick, P.; Cook, J. Predictive binding of $\beta$-carboline inverse agonists and antagonists via the CoMFA/GOLPF approach. J. Med. Chem. 1992, 35, 4001-4010.

82. Cain, M.; Weber, R. W.; Guzman, F.; Cook, J. M.; Barker, S. A.; Rice, K. C.; Crawley, J. N.; Paul, S. M.; Skolnick, P. $\beta$-Carbolines: Synthesis and neurochemical and pharmacological actions on brain benzodiazepine receptors. J. Med. Chem. 1982, 25, 1081-1091.

83. Hagen, T. J.; Skolnick, P.; Cook, J. M. Synthesis of 6-substituted $\beta$-carbolines that behave as benzodiazepine receptor antagonists or inverse agonists $J$. Med. Chem. 1987, 30, 750-753.

84. Cook, J. M.; Diaz-Arauzo, H.; Allen, M. S. Inverse agonists, probes to study the structure, topology and function of the benzodiazepine receptor. NIDA Res. Monogr. 1990, 133-139.

85. Schweri, M.; Cain, M.; Cook, J. M.; Paul, S.; Skolnick, P. Blockade of 3-carbomethoxy- $\beta$ carboline induced seizures by diazepam and the benzodiazepine antagonists, Ro 15-1788 and CGS 8216. Pharmaco. Biochem. Behav. 1982, 17, 457-460.

86. Fryer, R. I.; Cook, C.; Gilman, N. W.; Walser, A. Conformational shifts at the benzodiazepine receptor related to the binding of agonists, antagonists and inverse agonists. Life Sci. 1986, 39, 19471957.

87. Trullas, R.; Ginter, H.; Jackson, B.; Skolnick, P.; Allen, M. S.; Hagen, T. J.; Cook, J. M. 3Ethoxy- $\beta$-carboline: a high affinity benzodiazepine receptor ligand with partial inverse agonist properties. Life Sci. 1988, 43, 1193-1197.

88. Cox, E. D.; Diaz-Arauzo, H.; Huang, Q.; Reddy, M. S.; Harris, B.; Mckernan, R. M.; Skolnick, P.; Cook, J. M. Synthesis and evaluation of analogues of the partial agonist 6-(propyloxy)-4- 
(methoxymethyl)-beta-carboline-3-carboxylic acid ethyl ester (6-PBC) and the full agonist 6(benzyloxy)-4-(methoxymethyl)-beta-carboline-3-carboxylic acid ethyl ester (Zk 93423) at wild type and recombinant GABA(A) receptors. J. Med. Chem. 1998, 41, 2537-52.

89. Ninan, P. T.; Insel, T. M.; Cohen, R. M.; Cook, J. M.; Skolnick, P.; Paul, S. M. Benzodiazepine receptor-mediated experimental "anxiety" in primates. Science 1982, 218, 1332-1334.

90. Shannon, H. E.; Guzman, F.; Cook, J. M. $\beta$-Carboline-3-carboxylate-t-butyl ester: a selective BZ1 benzodiazepine receptor antagonist. Life Sci. 1984, 35, 2227-2236.

91. Mendelson, W. B.; Cain, M.; Cook, J. M.; Paul, S. M.; Skolnick, P. A benzodiazepine receptor antagonist decreases sleep and reverses the hypnotic actions of flurazepam. Science 1983, 219, 414-416. 92. Hagen, T. J.; Guzman, F.; Schultz, C.; Cook, J. M.; Shannon, H. E. Synthesis of 3,6disubstituted $\beta$-carbolines which possess either benzodiazepine antagonist or agonist activity. Heterocycles 1986, 24, 2845-2855.

93. Allen, M. S.; Hagen, T. J.; Trudell, M. L.; Codding, P. W.; Skolnick, P.; Cook, J. M. Synthesis of novel 3-substituted $\beta$-carbolines as benzodiazepine receptor ligands: probing the benzodiazepine receptor pharmacophore. J. Med. Chem. 1988, 31, 1854-1861.

94. Diaz-Arauzo, H.; Evoniuk, G. E.; Skolnick, P.; Cook, J. M. The agonist pharmacophore of the benzodiazepine receptor. Synthesis of a selective anticonvulsant/anxiolytic J. Med. Chem. 1991, 34, 1754-1756.

95. Wafford, K. A.; Bain, C. J.; Whiting, P. J.; Kemp, J. A. Functional comparison of the role of $\gamma$

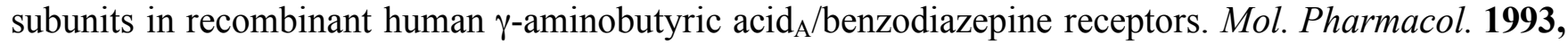
44, 437-442.

96. Braestrup, C.; Nielsen, M. GABA reduces binding of 3H-methyl $\beta$-carboline-3-carboxylate to brain benzodiazepine receptors. Nature 1981, 294, 472-474.

97. Venault, P.; Chapouthier, G.; de-Carvalho, L. P.; Simiand, J.; Morre, M.; Dodd, R. H.; Rossier, J. Benzodiazepine impairs and $\beta$-carboline enhances performance in learning and memory tasks. Nature 1986, 321, 864-866.

98. Lippke, K. P.; Schunack, W. G.; Wenning, W.; Müller, W. E. $\beta$-Carbolines as benzodiazepine receptor ligands. 1. Synthesis and benzodiazepine receptor interaction of esters of $\beta$-carboline-3carboxylic acid. J. Med. Chem. 1983, 26, 499-503.

99. Corda, M. G.; Blaker, W. D.; Mendelson, W. B.; Guidotti, A.; Costa, E. $\beta$-Carbolines enhance shock-induced suppression of drinking in rats. Proc. Natl. Acad. Sci. USA 1983, 80, 2072-2076.

100. Havoundjian, H.; Reed, G. F.; Paul, S. M.; Skolnick, P. Protection against the lethal effects of pentobarbital in mice by a benzodiazepine receptor inverse agonist, 6,7-dimethoxy-4-ethyl-3carbomethoxy- $\beta$-carboline. J. Clin. Invest. 1987, 79, 473-477.

101. Hadingham, K. L.; Wingrove, P.; Le-Bourdelles, B.; Palmer, K. J.; Ragan, C. I.; Whiting, P. J. Cloning of cDNA sequences encoding human $\alpha_{2}$ and $\alpha_{3} \gamma$-aminobutyric acid $a_{A}$ receptor subunits and characterization of the benzodiazepine pharmacology of recombinant $\alpha_{1^{-}}, \alpha_{2^{-}}, \alpha_{3^{-}}$, and $\alpha_{5}$-containing

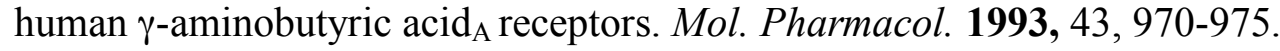

102. Hadingham, K. L.; Wingrove, P.; Le-Bourdelles, B.; Palmer, K. J.; Ragan, C. I.; Whiting, P. J. Cloning of cDNA sequences encoding human $\alpha_{2}$ and $\alpha_{3} \gamma$-aminobutyric acid $a_{A}$ receptor subunits and characterization of the benzodiazepine pharmacology of recombinant $\alpha_{1^{-}}, \alpha_{2^{-}}, \alpha_{3^{-}}$, and $\alpha_{5}$-containing

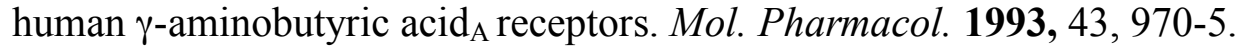

103. Sanger, D. J.; Benavides, J.; Perrault, G.; Morel, E.; Cohen, C.; Joly, D.; Zivkovic, B. Recent Developments in the Behavioral Pharmacology of Benzodiazepine-(Omega) Receptors - Evidence for the Functional-Significance of Receptor Subtypes. Neuroscience and Biobehavioral Reviews 1994, 18, 355-372.

104. McKernan, R. M.; Rosahl, T. W.; Reynolds, D. S.; Sur, C.; Wafford, K. A.; Atack, J. R.; Farrar, J.; Cook, G.; Ferris, P.; Garrett, L.; Bristow, L.; Marshall, G.; Macaulay, A.; Brown, N.; Howell, O.; Moore, K. W.; Carling, R. W.; Street, L. J.; Castro, J. L.; Ragan, C. I.; Dawson, G. R.; Whiting, P. J. Sedative but not anxiolytic properties of benzodiazepines are mediated by the $\mathrm{GABA}_{(\mathrm{A})}$ receptor alpha1 subtype. Nat Neurosci. 2000, 3, 587-592.

105. Griebel, G.; Perrault, G.; Letang, V.; Grainger, P.; Avenet, P.; Schoemaker, H. New Evidence 
that the Pharmacological Effects of Benzodiazepine Receptor Ligands can be Associated with Activities at Different BZ $(\alpha)$ Receptor Subtypes. Psychopharmacol. 1999, 146, 205-213.

106. June, H. L.; Foster, K. L.; McKay, P. F.; Seyoum, R.; Woods, J. E.; Harvey, S. C.; Eiler, W. J. A.; Grey, C.; Carroll, M. R.; McCane, S.; Jones, C. M.; Yin, W. Y.; Mason, D.; Cummings, R.; Garcia, M.; Ma, C. R.; Sarma, P.; Cook, J. M.; Skolnick, P. The reinforcing properties of alcohol are mediated by GABA(A1) receptors in the ventral pallidum. Neuropsychopharmacol. 2003, 28, 2124-2137.

107. Criswell, H. E.; Simson, P. E.; Duncan, G. E.; Mc Cown, T. J.; Herbert, J. S.; Morrow, L. Molecular Basis for Regionally Specific Action of Ethanol on $\gamma$-Aminobutyric Acida Receptors: Generalization to Other Ligand-Gated Ion Channels. J. Pharmacol. Exper. Ther. 1993, 267, 522-527.

108. Braestrup, C.; Nielsen, M.; Olsen, R. Urinary and brain $\beta$-carboline-3-carboxylates as potent inhibitors of brain benzodiazepine receptors. Proc. Natl. Acad. Sci. USA 1980, 77, 2288-2292.

109. Nielsen, M.; Braestrup, C. Ethyl $\beta$-carboline-3-carboxylate shows differential benzodiazepine receptor interaction. Nature 1980, 286, 606-607.

110. Huang, H.; He, X.; Ma, C. R.; Liu, R. Y.; Yu, S.; Dayer, C. A.; Wenger, G. R.; McKernan, R.; Cook, J. M. Pharmacophore/receptor models for $\mathrm{GABA}_{\mathrm{A}} / \mathrm{BzR}$ subtypes $(\alpha 1 \beta 3 \gamma 2, \alpha 5 \beta 3 \gamma 2$, and $\alpha 6 \beta 3 \gamma 2)$ via a comprehensive ligand-mapping approach. J. Med. Chem. 2000, 43, 71-95.

111. Huang, Q.; Cox, E. D.; Gan, T.; Ma, C. R.; Bennett, D. W.; Mckernan, R. M.; Cook, J. M. Studies of molecular pharmacophore/receptor models for $\mathrm{GABA}_{\mathrm{A}}$ /benzodiazepine receptor subtypes: Binding affinities of substituted $\beta$-carbolines at recombinant alphalbeta3gamma 2 subtypes and quantitative structure-activity relationship studies via a Comparative Molecular Field Analysis. Drug. Des. Discov. 1999, 16, 55-76.

112. Yin, W.; Sarma, P. V. V. S.; Ma, J.; Han, D.; Chen, J. L.; Cook, J. M. Synthesis of bivalent ligands of $\beta$-carboline-3-carboxylates via a palladium-catalyzed homocoupling process. Tetrahedron Letters 2005, 46, 6363-6368.

113. Portoghese, P. S. From models to molecules: Opioid receptor dimers, bivalent ligands, and selective opioid receptor probes. J. Med. Chem. 2001, 44, 2259-2269.

114. Portoghese, P. S.; Lin, C. E.; Farouzgrant, F.; Takemori, A. E. Structure-Activity Relationship of N17'-Substituted Norbinaltorphimine Congeners - Role of the N17' Basic Group in the Interaction with a Putative Address Subsite on the Kappa-Opioid Receptor. J. Med. Chem. 1994, 37, 1495-1500.

115. Halazy, S. G-protein coupled receptors bivalent ligands and drug design. Expert Opinion on Therapeutic Patents 1999, 9, 431-446.

116. Barnard, E.; Skolnick, P.; Olsen, R.; Möhler, H.; Sieghart, W.; Biggio, G.; Braestrup, C.; Bateson, A.; Langer, S. International union of pharmacology. XV. Subtypes of $\gamma$-aminobutyric $\operatorname{acid}_{(A)}$ receptors: classification on the basis of subunit structure and function. J. Pharmacol. Exp. Ther.(Pharmacol. Rev.) 1998, 50, 291-313.

117. June, H. L., Sr.; Foster, K. L.; Eiler, W. J. A. I.; Goergen, J.; Cook, J. B.; Johnson, N.; MensahZoe, B.; Simmons, J. O.; June, H. L., Jr.; Yin, W.; Cook, J. M.; Homanics, G. E. Dopamine and benzodiazepine-dependent mechanisms regulate the EtOH-enhanced locomotor stimulation in the $\mathrm{GABA}_{(\mathrm{A})} \alpha_{1}$ subunit null mutant mice. Neuropsychopharmacol. 2007, 32, 137-152.

118. Bell, R. L.; Lumeng, L.; Murphy, J. M.; McBride, W. J. The alcohol-preferring P rat and animal models of excessive alcohol drinking. Addict. Biol. 2006, 11, 270-288.

119. Koob, G. F. A Role for GABA Mechanisms in the Motivational Effects of Alcohol Biochem Pharmacol. 2004, 68, 1515-1525 (review and references therein).

120. Clayton, T., Chen, J.L., Ernst, M., Richter, L., Cromer, B.A., Morton, H.Ng, Kaczorowski, C.C., Helmstetter, F.J., Furtmuller, R., Ecker, G., Parker, M.W., Sieghart, W., Cook, J.M. Analysis of the Benzodiazepine Binding Site on $\gamma$-Aminobutyric acidA Receptors:

Correlation of Experimental Data with Pharmacophore and Comparative Models. Curr. Med. Chem. 2007, 14, 2755-2775.

121. Cromer, B.; Morton, C.; Parker, M. W. Cromer's model, Anxiety of GABA(A) receptor structure relieved by AChBP. Trends Biochem. Sci. 2002, 27, 280-287.

122. Trudell, J. R. Unique assignment of inter-subunit association in GABA(Alpha) alpha 1 beta 3 gamma 2 receptors determined by molecular modeling. Biochim. Biophys. Acta 2002, 1565, 91-96. 
123. Ma, C. Part one, Efficient asymmetric synthesis of ring-A substituted tryptophans : synthesis of 6-methoxy-(D)-tryptophan required for the total synthesis of ring-A oxygenated indole alkaloids. Part two, Syntheses of selective ligands for GABAA/benzodiazepine receptor subtypes Ph. D. Thesis, University of Wisconsin -Milwaukee, Milwaukee, WI, 2000.

124. Ramachandran, P. V.; Teodorovic, A. V.; Brown, H. C. Chiral synthesis via organoboranes. 38. Selective reductions. 48. Asymmetric reduction of trifluoro-methyl ketones by Bchlorodiisopinocampheylborane in high enantiomeric purity. Tetrahedron 1993, 49, 1725-1738.

125. Ramachandran, P. V.; Gong, B.; Brown, H. C. Chiral synthesis via organo-boranes. 40. Selective reductions. 55. A simple one-pot synthesis of the enantio-mers of trifluoromethyloxirane. A general synthesis in high optical purities of $\alpha$-trifluoromethyl secondary alcohols via the ring-cleavage reactions of the epoxide J. Org. Chem. 1995, 60, 41-46.

126. Sonogashira, K.; Tohda, Y.; Hagihara, N. Convenient synthesis of acetylenes. Catalytic substitutions of acetylenic hydrogen with bromo alkenes, iodo arenes, and bromopyridines. Tetrahedron Lett. 1975, 50, 4467-4470.

127. Sonogashira, K. Development of $\mathrm{Pd}-\mathrm{Cu}$ catalyzed cross-coupling of terminal acetylenes with $\mathrm{sp}^{2}$-carbon halides. Organometal. Chem. 2002, 653, 46-49.

128. Lei, A.; Srivastava, M.; Zhang, X. Transmetalation of palladium enolate and its application in palladium-catalyzed homocoupling of alkynes: a room-temperature, highly efficient route to make diynes. J. Org. Chem. 2002, 67, 1969-71.

129. Lüddens, H.; Korpi, E. R.; Seeburg, P. H. GABA $/$ /benzodiazepine receptor heterogeneity: neurophysiological implications. Neuropharmacol. 1995, 34, 245-254, Review.

130. Huang, Q.; Zhang, W. J.; Liu, R. Y.; McKernan, R. M.; Cook, J. M. Benzo-fused benzodiazepines employed as topological probes for the study of benzodiazepine receptor subtypes. Med. Chem. Res. 1996, 6, 384-391.

131. Huang, Q.; Liu, R. Y.; Zhang, P. W.; He, X. H.; McKernan, R.; Gan, T.; Bennett, D. W.; Cook, J. M. Predictive models for $\operatorname{GABA}(\mathrm{A}) /$ benzodiazepine receptor subtypes: Studies of quantitative structure-activity relationships for imidazobenzodiazepines at five recombinant GABA(A)/benzodiazepine receptor subtypes [alpha $\mathrm{x}$ beta 3 gamma $2(\mathrm{x}=1-3$, 5, and 6)] via comparative molecular field analysis. J. Med.Chem. 1998, 41, 4130-4142.

132. He, X. B.; Huang, Q.; Ma, C. R.; Yu, S.; McKernan, R.; Cook, J. Pharmacophore/receptor models for $\mathrm{GABA}_{\mathrm{A}} / \mathrm{BzR}$ a2b3g2, a3b3g3, and a4b3g2 recombinant subtypes. Included volume analysis and comparison to a1b3g2, a5b3g2 and a6b3g2 subtypes Drug Des. Discov. 2000, 17, 131-171.

133. O'mara, M.; Cromer, B.; Parker, M.; Chung, S. H. Homology model of the GABAA receptor examined using Brownian dynamics. Biophys. J. 2005, 88, 3286-99.

134. Arnold, K.; Bordoli, L.; Kopp, J.; Schwede, T. The SWISS-MODEL Workspace: A web-based environment for protein structure homology modeling. Bioinformatics 2006, 22, 195-201.

135. Buhr, A.; Baur, R.; Sigel, E. Subtle changes in residue 77 of the gamma subunit of alpha 1 beta 2 gamma 2 GABA(A) receptors drastically alter the affinity for ligands of the benzodiazepine binding site. J. Biol. Chem. 1997, 272, 11799-11804.

136. Buhr, A.; Schaerer, M. T.; Baur, R.; Sigel, E. Residues at positions 206 and 209 of the alpha 1 subunit of gamma-aminobutyric acid(A) receptors influence affinities for benzodiazepine binding site ligands. Mol. Pharmacol. 1997, 52, 676-682.

137. Buhr, A.; Sigel, E. A point mutation in the gamma(2) subunit of gamma-aminobutyric acid type A receptors results in altered benzodiazepine binding site specificity. Proc. Natl. Acad. Sci. U.S.A. 1997, 94, 8824-8829.

138. Mihic, S. J.; Whiting, P.; Klein, R. L.; Wafford, K.; Harris, R. A. A single amino acid of the human $\gamma$-aminobutyric acid type A receptor $\gamma 2$ subunit determines benzodiazepine efficacy. J. Biol. Chem. 1994, 269, 32768-32773.

139. Sigel, E.; Schaerer, M. T.; Buhr, A.; Baur, R. The benzodiazepine binding pocket of

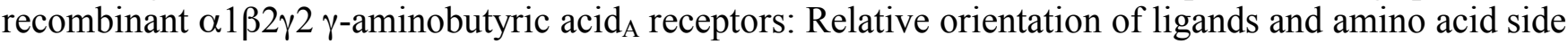
chains. Mol. Pharmacol. 1998, 54, 1097-1105.

140. Choudhary, M. S., Craigo, S., Roth, B.L. Mol. Pharmacol. 1992, 42, 627-633.

141. Braestrup, C.; Honore, T.; Nielsen, M. C.; Peterson, E. N.; Jensen, L. H. Ligands for 
benzodiazepine receptors with positive and negative efficacy. Biochem. Pharmacol. 1984, 33, 859-862. 142. Lawson, J.; Uyeno, E. T.; Nienow, J.; Loew, G. H.; Toll, L. Structure-activity studies of $\beta$ carboline analogs. Life Sci. 1984, 34, 2007-2013.

143. Huang, Q.; Cox, E.; Gan, T.; Ma, C. R.; Bennett, D. A.; McKernan, R.; Cook, J. Studies of molecular pharmacophore/receptor models for $\mathrm{GABA}_{\mathrm{A}} /$ benzodiazepine receptor subtypes: Binding affinities of substituted $\beta$-carbolines at recombinant alpha1beta3gamma2 subtypes and quantitative structure-activity relationship studies via a comparative molecular field analysis. Drug Des. Discov. 1999, 16, 55-76.

144. Hanzawa, Y.; Kawagoe, K.; Ito, M.; Kobayashi, Y. Kinetic resolution of (E)[(fluoroalkyl)vinyl]carbinol derivatives by asymmetric epoxidation with titanium-tartrate catalysts. Chem. Pharm. Bull. 1987, 35, 1633-1636.

145. Liu, R.; Zhang, P.; Gan, T.; Mckernan, R. M.; Cook, J. M. Evidence for the conservation of conformational topography at five major $\mathrm{GABA}_{(\mathrm{A})}$ /benzodia-zepine receptor subsites. Potent affinities of the (S)-enantiomers of framework-constrained 4,5-substituted pyrroloimidazobenzodiazepines. Med. Chem. Res. 1997, 7, 25-35.

146. Saiga, Y.; Iijima, I.; Ishida, A.; Miyagishima, T.; Shigezane, K.; Oh-Ishi, T.; Matsumoto, M.; Matsuoka, Y. Synthesis of 1,2,3,4-tetrahydro-b-carboline derivatives as hepatoprotective agents. II. Alkyl 1,2,3,4-tetrahydro-b-carboline-2-carbodithioates. Chem. Pharm. Bull. 1987, 35, 3262-3269.

147. Eftink, M. R.; Jia, J.; Hu, D.; Ghiron, C. A. Fluorescence studies with tryptophan analogs: excited state interactions involving the side chain amino group. J. Phy. Chem. 1995, 99 5713-5723.

148. Plate, R.; Nivard, R. J. F.; Ottenheijm, H. C. J.; Kardos, J.; Simonyi, M. Synthesis and pharmacological activity of $\mathrm{C}(1)$ - and N(2)-substituted b-carboline derivatives. Heterocycles 1986, 24, 3105-3114.

149. Moody, C. J.; Ward, J. G. [2,3] Fused indoles. Synthesis of b-carbolines and azepino[4,5b]indoles from 3-(2-alkylindol-3-yl)-2-azidoacrylates. J. Chem. Soc. Perkin Trans. 1 1984, 12, 28952901 